\title{
The Unity of Aristotle's Metaphysics
}

\section{Book E according to the Interpretation of the Ancient Commentators}

Rita Salis

This paper discusses the three ancient commentaries on Book E of Aristotle's Metaphysics, that have been handed down to us. It aims to demonstrate the fundamental part played by their particular interpretation of Aristotle's doctrines in the birth of the traditional interpretation of his Metaphysics, according to which all the books comprising the work were written as a function of Book $\Lambda$, containing the well-known doctrine of the unmoved mover. Among the main elements supporting this assumption there is Aristotle's distinction between three types of science - the theoretical, the practical and the productive - and his claiming the primacy of metaphysics as a theological science. According to the ancient commentators, the remainder of Book E would belong to the unitary project of the Metaphysics, since it would indicate what is not encompassed in the object of metaphysics. This would mean that Aristotle's treatment of accidental being, being as truth and not-being as falsity, and being potentially and actually would take on a negative function. The theological interpretation of Aristotle's Metaphysics thus retains its ultimate foundations in premises contained in the Aristotelian text itself.

\section{Introduction}

This paper aims to demonstrate that one of the essential foundations for the theologizing interpretation of Aristotle's metaphysics that characterizes the whole tradition of the ancient commentaries, according to which all the books in the Metaphysics would be steps along a path towards the divine substance (a topic developed, as we know, in the second part of Book $\Lambda$ ), lies in the ancient commentators' interpretation of Book E. The ancient commentaries on Book $\mathrm{E}$ that have been handed down to us were written by Asclepius ${ }^{1}$, pseudo-Alexander ${ }^{2}$, and pseudo-Philoponus. ${ }^{3}$ Asclepius's commentary only covers Books A-

${ }^{1}$ Cf. Asclepii In Aristotelis Metaphysicorum libros A-Z commentaria (CAG 6.2), edidit Michael Hayduck, Berolini 1888.

2 Alexandri Aphrodisiensis In Aristotelis Metaphysica commentaria (CAG 1), edidit Michael Hayduck, Berolini 1891.

${ }^{3}$ Pseudo-Johannis Philoponi Expositiones in Omnes Z Aristotelis Libros Metaphysicos (CAGL 2), Übersetzt Franciscus Patritius, Neudruck der ersten Ausgabe Ferrara 1583 mit einer Einleitung von Charles Lohr (Stuttgart-Bad Cannstatt 1991). 
Z. It echoes the oral teachings of Ammonius, head of the Neoplatonic school of Alexandria, and draws on the commentary on Aristotle's Metaphysics by Alexander of Aphrodisias. ${ }^{4}$ The commentary by pseudo-Philoponus (wrongly attributed to John Philoponus) has only reached us in the Latin version. The author quotes a passage from pseudo-Alexander's commentary on Book E, attributing it to Michael of Ephesus ${ }^{5}$ - and this becomes the most important clue to the non-authenticity of the latter commentary. ${ }^{6}$ Pseudo-Alexander's work is distinctive for its breadth and its particular place in the history of the Aristotelian tradition: his commentary on Book E was the first of the commentaries on the books of the Metaphysics to be attributed for centuries to Alexander of Aphrodisias (the greatest of the ancient commentators on Aristotle), and subsequently acknowledged as inauthentic. Although most manuscripts attribute the whole work to Alexander, in manuscript A (Parisinus graecus 1876, $13^{\text {th }}$ century) somebody placed the name of the byzantine Michael of Ephesus $\left(11^{\text {th }}-12^{\text {th }}\right.$ centuries $)$ before the title of the commentary on Book E. ${ }^{7}$ That the commentary on Books E-N handed down to us is not the authentic commentary by Alexander is confirmed by the fact that Asclepius's commentary on Book Z includes three quotations from Alexander that are nowhere to be found in the commentary on the same book which came down to us. ${ }^{8}$ We can also find many passages in the Syrianus's commentary on Books $\mathrm{M}$ and $\mathrm{N}$ that are the same as those appearing in the inauthentic commentary: this means that, if Syrianus were to have relied on pseudo-Alexander as a source, then it is impossible to identify the latter with Michael of Ephesus. Robert W. Sharples demonstrated, however, that pseudo-Alexander is

${ }^{4}$ Asclepius, In Metaph., pp. 167, 35-168, 18 = Alexander, In Metaph., pp. 196, 31-197, 21; Asclepius, In Metaph., p. 169, 1-11 = Alexander, In Metaph., p. 198, 1-11; Asclepius, In Metaph., p. 170, 3-16 = Alexander, In Metaph., p. 198, 16-30.

${ }^{5}$ Cf. pseudo-Philoponus, In Metaph., p. 25 r: "Ephesius autem proprie entia dicit, singulares

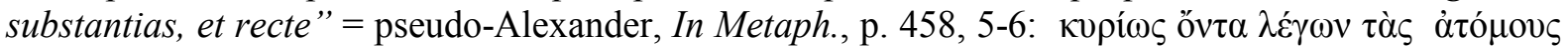
ov̉oías.

${ }^{6}$ Cf. Paul Moraux, Alexandre d'Aphrodise, exégète de la Noétique d'Aristote, (Liège, Faculté de philosophie et lettres and Paris, Droz 1942), p. 15; Sten Ebbesen, Commentators and Commentaires on Aristotle's Sophistici Elenchi: A Study of Post-Aristotelian Ancient and Medieval Writings on Fallacies, vol. III, Appendix 8 (Leiden, Brill 1981), p. 87; Stefan Alexandru, A New Manuscript of Pseudo-Philoponus' Commentary on Aristotle's 'Metaphysics' Containing a Hitherto Unknown Ascription of the Work, «Phronesis», 44 (1999), pp. 374-352, spec. p. 348.

${ }^{7}$ Cf. Hermann Bonitz, Alexandri Aphrodisiensis in Aristotelis Metaphysica commentaria, edidit Hermann Bonitz, (Berolini, Reimer 1847), Prefatio, p. XIV.

${ }^{8}$ Cf. Asclepius, In Metaph., pp. 408, 5-7; 408, 20 ff.; 428, 13 ff. Cf. Concetta Luna, Trois études sur la tradition des commentaires anciens à la Métaphysique d'Aristote, (Leiden-Boston-Köln, Brill 2001), p. 51 note 90. 
more likely to have relied on Syrianus. ${ }^{9}$ In the $16^{\text {th }}$ century, Juan Ginés de Sepúlveda - the author of the Latin version of the Alexander's and pseudo-Alexander's commentary on Aristotle's Metaphysics ${ }^{10}$ - rejected the opinion prevailing in his time that tended to identify pseudo-Alexander with Michael of Ephesus. He claimed that the author of the second part of the commentary was Alexander himself. ${ }^{11}$ Hermann Bonitz was of the same opinion, but he also held that the two parts of the work differed in style and content, and had come to us in a revised form, modified by a lesser author living after Alexander. ${ }^{12}$

Jacob Freudenthal was another to reject the idea that pseudo-Alexander was the Christian Michael. One reason for his conviction was the fact that numerous references to polytheism appeared in the commentary on Books E-N, and he accused pseudo-Alexander of being a forger, an imposter deliberately pretending to be the real Alexander. According to Freudenthal, pseudo-Alexander was a Neoplatonic living between the $5^{\text {th }}$ and $6^{\text {th }}$ centuries. ${ }^{13}$ Freudenthal's theory regarding the identification of pseudo-Alexander with a Neoplatonic was taken up by Leonardo Tarán, who nevertheless claimed that Syrianus had made use of

\footnotetext{
${ }^{9}$ In fact, Sharples demonstrated that Simplicius's comment on Aristotle, De caelo II 12 corresponds word for word to pseudo-Alexander's comment on Aristotle, Metaph. $\Lambda$ 8, 1074 a 13-14. But Simplicius's commentary contains a broader version of the text, and Sharples noted that the parts contained in Simplicius but not in pseudo-Alexander would support the reliance of pseudo-Alexander on Simplicius. Since Simplicius came after Syrianus, it follows that pseudo-Alexander also relied on Syrianus. Cf. Robert William Sharples, Pseudo-Alexander on Aristotle, Metaphysics $\Lambda$, in Giancarlo Movia (a cura), Alessandro di Afrodisia e la "Metafisica" di Aristotele, (Milano, Vita e Pensiero 2003), pp. 187-218. I discussed the question of pseudo-Alexander's identity in Rita Salis, Il commento di pseudo-Alessandro al libro $\Lambda$ della Metafisica di Aristotele (Soveria Mannelli, Rubbettino 2005), pp. 23-28; 371-374.

${ }^{10}$ Cf. Alexandri Aphrodisei Commentaria In duodecim Aristotelis libros de prima Philosophia, interprete Ioannes Genesius Sepulveda (Pariis 1536).

${ }^{11}$ Among the reasons mentioned by Sepulveda to support this theory there was the fact that most of the ancient manuscripts attributed the whole commentary to Alexander, and the observation that there would be no difference in style between the two parts of the commentary. This opinion was refuted by: Francesco Patrizi, who suggested that the author of the commentary on Books E-N was Alexander Aegeus (cf. Discussionum Peripateticarum, T. IV (Basel 1581), pp. 32-33); Brandis, who attributed the second part of the work to Michael of Ephesus or a later author (cf. Christian August Brandis, Scholia in Aristotelem, 734 a, in Aristotelis Opera, edidit Academia Regia Borussica, vol. IV, (Berolini 1836)); and Ravaisson, who identified pseudo-Alexander with Michael of Ephesus (cf. Félix Ravaisson, Essai sur la Metaphysique d'Aristote, vol. I, (Hildesheim, Olms 1963), pp. 64-65). Cf. also Luna, Trois études, p. 55 note 108.

${ }^{12}$ Bonitz, Metaph., Praefatio, pp. XIV-XXVII.

${ }^{13}$ Cf. Jacob Freudenthal, Die durch Averroes erhaltenen Fragmente Alexanders zur Metaphysik des Aristoteles untersucht und übersetzt, «Abhandlungen der königlichen Akademie der Wissenschaften zu Berlin», Berlin 1884, phil. hist. K1., no. 1, pp. 19 ff.; 27 ff.; 32-33; 53-54.
} 
pseudo-Alexander's work, mistaking it for the authentic commentary ${ }^{14}$, and that Simplicius had done so too. ${ }^{15}$ On the other hand, Karl Praechter supported the identification of pseudoAlexander with Michael, explaining the references to polytheism in the second part of the commentary with the claim that, in Michael's time, philosophy was separate from religion. ${ }^{16}$ Paul Moraux was of the same opinion and, unlike Freudenthal and Tarán, he believed that neither pseudo-Alexander nor Syrianus had made use of each other's commentaries, but that both had drawn on the same source, i.e. the authentic commentary of Alexander. ${ }^{17}$ Sharples justifies Freudenthal's observation that a Christian would have been unable to do what pseudo-Alexander did when, commenting on the final passage of Metaph. $\Lambda$, in which Aristotle declares the supremacy of a first principle, he concludes by saying that divinities are the causes of the wandering stars, even though they depend for their participation and will on the first and most blessed intelligence. ${ }^{18}$ According to Sharples, pseudo-Alexander may have meant to clarify the condition of the subordinate unmoved movers, or else this passage might have been included in the commentary from a pagan source. ${ }^{19}$ Finally, Concetta Luna showed that pseudo-Alexander is actually Michael of Ephesus on the grounds of precise textual comparisons. Among the reasons she advanced, one concerns the repeated use of terms and expressions that can only be found in works attributed to pseudo-Alexander and to Michael. ${ }^{20}$ To further support the identification of pseudo-Alexander with Michael, we might add that Freudenthal's theory that pseudo-Alexander actually wanted to appear as the real Alexander is hard to defend because in antiquity the idea of presenting a spurious work as authentic had yet to be conceived. ${ }^{21}$ The references to polytheism contained in the last passage of pseudoAlexander's commentary could be seen as reflecting the Greek conception of the divine. ${ }^{22}$

${ }^{14}$ Cf. Leonardo Tarán, Syrianus and pseudo-Alexander's commentary on Metaph. E-N, in Paul Moraux, Aristoteles Werk und Wirkung, Bd. 2: Kommentierung, Überlieferung, Nachleben, (Berlin, De Gruyter 1987), pp. 215-232, spec. pp. 223 ff.

${ }^{15}$ Cf. Tarán, Syrianus, p. 230 and note 42.

${ }^{16}$ Cf. Karl Praechter, review on $C A G$ XXII, 2, in «Göttingische gelehrte Anzeigen», 11, 1906, pp. 882-899, spec. pp. 882-896.

${ }^{17}$ Paul Moraux, Der Aristotelismus bei den Griechen von Andronikos bis Alexander von Aphrodisias, Bd. 3: Alexander von Aphrodisias, herausgegeben Jürgen Wiesner, (Berlin-New York, De Gruyter 2001), pp. 423 ff.; Moraux, Alexandre d'Aphrodise, pp. 14-19.

${ }^{18}$ Cf. pseudo-Alexander, In Metaph., p. 721, 32-33.

${ }^{19}$ Cf. Sharples, Pseudo-Alexander on Aristotle, p. 191.

${ }^{20}$ Per es. $\mu \varepsilon \mu \varepsilon \lambda \alpha \nu \omega \mu \varepsilon ́ v \omega \varsigma$ (cf. Luna, Trois études, p. 35 and note 62).

${ }^{21}$ Cf. Sharples, Pseudo-Alexander on Aristotle, pp. 191-192 and note 27.

${ }^{22}$ This is what I claimed in Il commento di pseudo-Alessandro, p. 28. 


\section{The distinction between the sciences and theological science}

For the ancient commentators, acknowledging the unity of Aristotle's Metaphysics posed the serious problem of having to justify steps along the metaphysical path that were clearly not directly pertinent to the development of the science being investigated. The case of Book E is particularly emblematic because the first chapter discusses theological science and claims its primacy over the other sciences, but then the other three chapters are clearly dedicated to different topics from first philosophy, making it difficult for the ancient commentators to explain their role. Asclepius's commentary on Metaph. E begins with several significant general considerations on the topic of the book. The commentator explicitly states that Aristotle's aim was to deal with accidental being, being as truth and notbeing as falsity, and being potentially and actually in order to demonstrate that first philosophy, the object of which is all beings qua beings, must only focus on being per se in each category. Asclepius goes on to say that the first philosopher will not be concerned with accidental being because this is indeterminate, nor will he consider being as truth and notbeing as falsity, even though it is determinate, because he will only be interested in being 'in general' ( $\dot{\alpha} \pi \lambda \tilde{\omega} \varsigma)$, that is the simplest being ( $\dot{\alpha} \pi \lambda o v \sigma \tau \dot{\alpha} \tau o v)$. Truth and falsity will concern combination and separation. First philosophy will not be concerned with being potentially and actually either, as it will focus on being per se. In Book E, Aristotle will only concern himself with demonstrating that philosophy can be divided into theoretical and practical sciences, since philosophy cannot be a productive science because its purpose is to gain knowledge. ${ }^{23}$ So, according to Asclepius, the purpose of Book E, in discussing the four principal meanings of being, would be to demonstrate that first philosophy cannot be concerned with accidental being, or with being as truth and not-being as falsity, nor even adds the commentator, going a step beyond Aristotle - with being potentially and actually. It can only focus on the absolutely simplest being, i.e. on the being according to the figures of the categories. Book E would thus acquire a negative function within the Metaphysics, since Aristotle would use it to show which meanings of being should not be the object of study by the first philosopher.

Pseudo-Philoponus tries to solve the problem concerning the topic of Book E by claiming that the science of being qua being is only sketched out here, to be further developed in ${ }^{23}$ Cf. Asclepius, In Metaph., pp. 358, 4-359, 16. 
subsequent books in the Metaphysics. It is important to mention that some lines from pseudoPhiloponus's commentary coincide almost word for word with parts of pseudo-Alexander's text. ${ }^{24}$ As mentioned earlier, and as we shall see later on, that a relationship existed between the two commentaries is also demonstrated by pseudo-Philoponus's reference to the man from Ephesus (meaning Michael of Ephesus) on the matter of a passage in E 4. ${ }^{25}$ This goes to show that it was pseudo-Philoponus who drew on pseudo-Alexander's work, and supports the conviction that pseudo-Alexander and Michael of Ephesus were one and the same.

In the brief prologue to his work on Metaph. E, pseudo-Alexander seems to come closer to pseudo-Philoponus than to Asclepius. In fact, pseudo-Alexander recalls Aristotle's definition of the object of first philosophy as a science that focuses on being qua being, in Book $\Gamma \cdot{ }^{26}$ But in the incipit of Metaph. E 1, this definition is combined with the definition of first philosophy as a science of causes and principles. ${ }^{27}$ A little later on, Aristotle distinguishes the special sciences from the science of being qua being, saying that the former are concerned with a certain genus of being, while the latter deals with being simply and qua being. ${ }^{28}$ Anticipating the passage in Aristotle, pseudo-Alexander uses the example of astronomy, which he says focuses not on the nature of beings, but on their properties. In the incipit of his commentary, the topic of Book $\mathrm{E}$ is thus brought down to the science which we are seeking, in an attempt to save the unitary conception of the Metaphysics as a whole. Pseudo-Alexander is nonetheless obliged to acknowledge that the science of being qua being is not very clearly presented in Book $\mathrm{E}$, and he refers the reader to Book $\mathrm{Z}$ for a less obscure explanation, and to subsequent books for an in-depth treatment of the concept. ${ }^{29}$ In the last

${ }^{24}$ Cf. pseudo-Philoponus, In Metaph., p. 24 r: Illam dicens scire ens ut ens, quae cuiusque definitionem novit. Sive intelligibile illud sit, siv.e aliud quippiam et quorum sunt definitiones, et

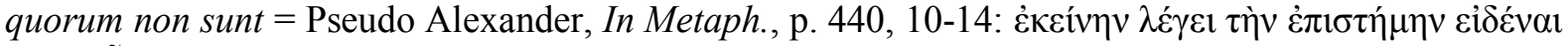

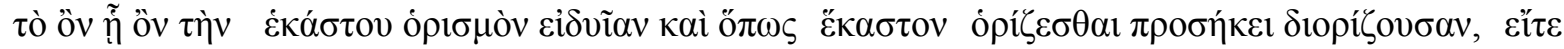

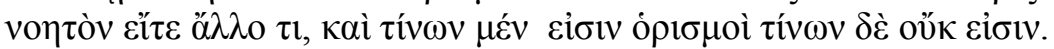

${ }^{25} \mathrm{Cf}$. infra, $\S 4$.

${ }^{26}$ Cf. pseudo-Alexander, In Metaph., p. 440, 3-4.

${ }^{27}$ Cf. Aristotle, Metaph. E 1, 1025 b 1-2. Cf. Giancarlo Movia, Introduzione a Giancarlo Movia (ed.), Alessandro di Afrodisia e pseudo-Alessandro, Commentario alla "Metafisica" di Aristotele (Milano, Bompiani 2007), p. LXXIX.

${ }^{28}$ Cf. Aristotle, Metaph. E 1, 1025 b 7-10. Cf. Movia, Introduzione, p. LXXIX.

${ }^{29}$ Cf. pseudo-Alexander, In Metaph., p. 440, 6-10. Pseudo-Alexander rightly points out that Book E does not contain a complete discussion of the science of being qua being. In fact, this is the science of the primary meanings of being, and it had been established in Metaph. $\Gamma$ that they are several, and converge in their principal meaning, i.e. in the substance. In Metaph. $\Delta 7$ it is also stated that there are four such meanings: accidental being, being per se, being as truth and not-being as falsity, and being 
part of his prologue, pseudo-Alexander claims that, according to Aristotle, the science of being qua being knows the definition of each entity, and establishes which entities have a definition and which do not. ${ }^{30}$ Movia suggests that, on the strength of Metaph. Z 4-6, the commentator probably intends to remind us that it is up to ontology to ascertain what has a definition, that is to identify the substance in the strict sense and, in a derivative way, the accidents. ${ }^{31}$ In fact, pseudo-Alexander seems to anticipate the content of the subsequent book, as if to make up for a shortcoming in Book E.

Aristotle's claim that every science which is ratiocinative or that involves reasoning deals with more or less precise causes and principles is exemplified by health and good condition on the one hand, and by mathematics on the other. ${ }^{32}$ Pseudo-Alexander faithfully provides the same examples ${ }^{33}$, while for the sciences that are ratiocinative the commentator speaks of the practical sciences. ${ }^{34}$ As an example of sciences of which the principles are more precise, pseudo-Alexander mentions geometry, while he suggests astronomy and medicine as sciences of which the principles are less exact. ${ }^{35}$ The same examples (geometry and astronomy) appear in pseudo-Philoponus. ${ }^{36}$ Regarding the superiority of the principles of geometry, pseudo-Alexander had previously referred to the beginning of the De anima ${ }^{37}$, where - according to Movia - Aristotle probably wants to say that psychology is superior to the other special sciences both because of its strict method, and because of the value of the object it studies. ${ }^{38}$ Asclepius describes the theoretical sciences as those relying on reasoning

potentially and actually. Only two of these meanings of being are discussed in Book E (accidental being and being as truth), while it is in Book $\mathrm{Z}$ that Aristotle shows that the being par excellence is that of the first category, substance. He concerns himself with first substance in Book $\Lambda$, while he deals with being potentially and actually in book $\Theta$. Cf. Movia, Introduzione, p. LXXX.

${ }^{30}$ Cf. pseudo-Alexander, In Metaph., p. 440, 10-13.

${ }^{31}$ Cf. Movia, Introduzione, p. LXXX.

${ }^{32}$ Cf. Aristotle, Metaph. E 1, 1025 b 2-3.

${ }^{33}$ Cf. pseudo-Alexander, In Metaph., p. 441, 1-2.

${ }^{34}$ Cf. pseudo-Alexander, In Metaph., p. 441, 4. On this issue, Movia believes it more likely that Aristotle was referring to the sciences that are based on experience rather than on reasoning. Cf. Movia, Introduzione, p. LXXXI and note 9; cf. William David Ross, Aristotle's Metaphysics. A Revised Text with Introduction and Commentary, vol. I (Oxford-New York, Oxford University Press for Sandpiper Books 1997), p. 351.

${ }^{35}$ Cf. pseudo-Alexander, In Metaph., p. 441, 33-35.

${ }^{36}$ Cf. pseudo-Philoponus, In Metaph., p. 24 r.

${ }^{37}$ Cf. pseudo-Alexander, In Metaph., p. 441, 8-9.

${ }^{38}$ Cf. Aristotle, De an. I 1, 402 a 1-4. Cf. Movia, Introduzione, p. LXXXI and note 10, where it is also rightly mentioned that, while Aristotle does not compare explicitly geometry with astronomy in 
$(\lambda \hat{\gamma} \gamma \omega)$ alone, and he refers to geometry. Among the sciences in which reasoning somehow

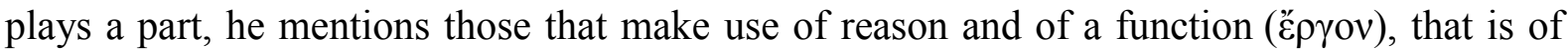
sensation, such as harmonic science (which is reliant on hearing). Anticipating what Aristotle claims in 1025 b 11-12, Asclepius explains that these sciences may be more strictly concerned with principles (relying exclusively on reason), or less so (relying on sensation and reason). As examples of sciences that deal with a part of being, the commentator mentions: medicine, which is concerned with the human body; astronomy, which focuses on the celestial bodies; and geometry, which deals with quantities. ${ }^{39}$ In pseudo-Philoponus's commentary, the difference between the sciences that make a more or less strict use of reasoning is described in the same terms as in Asclepius, thus anticipating $1025 \mathrm{~b} 11-12$. In fact, pseudo-Philoponus says that the special sciences are not concerned with the essence, but they assume it with sensation or supposition. ${ }^{40}$

Aristotle goes on to provide three reasons for the difference between first philosophy and the special sciences. As anticipated above, the first is that the special sciences have as their object only some particular being, whereas first philosophy investigates being simply ( $\dot{\alpha} \pi \lambda \tilde{\omega} \varsigma$ ) and qua being. ${ }^{41}$ Pseudo-Alexander explains that the special sciences study the causes of a given object, that is secondary causes, while first philosophy studies the causes of being in the absolute sense, qua being, or primary causes. ${ }^{42}$ The second reason is that instead of offering any discussion of the essence, the special sciences start from it (clarifying it and indicating $i^{43}$ as sensation, others assuming it hypothetically), and they more or less precisely demonstrate the properties that belong per se to the genus they are discussing. ${ }^{44}$ As examples of the first class of sciences, pseudo-Alexander mentions medicine and physics, and he specifies that it is up to the latter to demonstrate the principles of the former. ${ }^{45} \mathrm{He}$ includes

Metaph. E 1, the superiority of the principles of geometry emerges from Metaph. M 3, 1078 a 9-13, where it is claimed that the degree of preciseness of a science is proportional to the simplicity and preciseness of its object.

${ }^{39}$ Cf. Asclepius, In Metaph., p. 359, 15-20.

${ }^{40}$ Cf. pseudo-Philoponus, In Metaph., p. 24 r.

${ }^{41}$ Cf. Aristotle, Metaph. E 1, 1025 b 8-10.

${ }^{42}$ Cf. pseudo-Alexander, In Metaph., p. 441, 10-14; Movia, Introduzione, p. LXXXI.

${ }^{43}$ Cf. Christopher Kirwan, Aristotle, Metaphysics Books Gamma, Delta, and Epsilon, transl. with notes, (Oxford, Clarendon Press 1971, 1993², repr. 1998), p. 66.

${ }^{44}$ Cf. Aristotle, Metaph. E 1, 1025 b 10-13.

${ }^{45}$ Cf. pseudo-Alexander, In Metaph., p. 441, 16-24; Movia, Introduzione, pp. LXXXI-LXXXII and note 14, which refers to Aristotle, De an. I 1, 403 b 9-16; De sensu 1, 436 a 17-b 1; De Resp. 27, 480 b 22-30. 
mathematics in the second class of sciences, saying that arithmetic hypothesizes that unity is substance without position. ${ }^{46}$ Both pseudo-Alexander and Asclepius rightly refer to the Posterior Analytics ${ }^{47}$, and they both explain that, according to Aristotle, sciences cannot demonstrate their principles. $^{48}$ Pseudo-Alexander clarifies that each special science demonstrates the affections of its object, and of what pertains thereto. ${ }^{49}$ So, Aristotle sees neither the physical sciences nor the mathematical sciences as being concerned with the essence: the former assume it from sensation, the latter hypothetically, and both demonstrate that the attributes necessarily belong to their respective subjects by virtue of this assumed (but not demonstrated) essence. ${ }^{50}$ Pseudo-Alexander correctly explains this view, and he agrees. $^{51}$

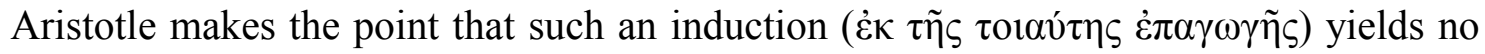
demonstration of either the substance or the essence ${ }^{52}$, and that there is another type of explanation for them. ${ }^{53}$ Movia considers it feasible that Aristotle might have used the term 'induction' to mean the manner of proceeding of the special sciences, i.e. the assumption of the essence starting from a perception or a hypothesis. In both procedures, the special sciences assume, but do not demonstrate the essence - something impossible to do, even for philosophy. Movia concludes that, for the essence, we therefore need a different type of explanation, instead of a demonstration, and this is a task for philosophy, with its problematic

${ }^{46}$ Cf. pseudo-Alexander, In Metaph., p. 441, 24-27. Cf. Aristotle, An. post. I 27, 87 a 36; Ross, Metaph., vol. I, p. 352; Movia, Introduzione, p. LXXXII and note 15, where, regarding the principle formulated in 441,27 , according to which things which are equal to the same thing are equal to each other, reference is made to Euclid's first axiom. The second definition of the point in 441, 26-27, as of that which has no part, corresponds to Euclid, I, def. 1 (cf. The Thirteen Books of Euclid's Elements with Introduction and Commentary by Sir Thomas Little Heath, vol. I (New York, Dover 1956²), ad loc.).

${ }^{47}$ Cf. pseudo-Alexander, In Metaph., p. 442, 1; Asclepius, In Metaph., p. 359, 28-29: cf. Aristotle, An. post. I 3.

${ }^{48}$ Cf. pseudo-Alexander, In Metaph., p. 441, 27-28; Asclepius, In Metaph., p. 359, 27. In 359, 29-32, Asclepius refers to the Almagest by Ptolomy, I 3, on the matter of astronomy, included among the sciences that infer the definition from sensation.

${ }^{49}$ Cf. pseudo-Alexander, In Metaph., p. 441, 28-31.

${ }^{50} \mathrm{Cf}$. Movia, Introduzione, p. LXXXII.

${ }^{51}$ Cf. pseudo-Alexander, In Metaph., p. 441, 27-38.

${ }^{52}$ Cf. Enrico Berti, Aristote. Métaphysique Livre Epsilon, Introduction, traduction et commentaire (Paris, Vrin 2015), p. 89, where it is believed that 'essence' and 'substance' in 1025 b 14 are synonymous.

${ }^{53}$ Cf. Aristotle, Metaph. E 1, 1025 b 14-16. 
or dialectic (rather than demonstrative) approach. ${ }^{54}$ Pseudo-Alexander only considers the case of the essence being assumed on the basis of sensation, that he associates with induction. The commentator emphasizes that a belief obtained by means of sensation and induction is not a demonstration. On this issue, he refers readers to the Posterior Analytics ${ }^{55}$, where Aristotle declares that demonstrations are universal, while a given object is perceived here and now. It is impossible to perceive the universal because it is neither this given thing, nor is it now. ${ }^{56}$ Then induction is set against demonstration: the former proceeds from particulars; the latter from universals. ${ }^{57}$ Pseudo-Alexander objects that somebody might admit of induction not being universal and, by virtue of this, he claims that a demonstration of the substance, of the essence, and of the definition clearly does not derive from said induction, but by another way, that Aristotle will explain in Book Z. ${ }^{58}$ According to Movia, however, Aristotle might answer that induction could not reach a universal conclusion unless all the species (e.g., 'man, 'horse, 'mule') of the genus (e.g., 'animal without bile') about which we mean to establish a universal proposition (e.g., 'all animals without bile are longaeval') have been assumed. ${ }^{59}$ The fact that pseudo-Alexander declares it impossible to demonstrate the essence seems to place him among those commentators who were the first to attribute a non-demonstrative function to first philosophy. ${ }^{60}$ Berti believes, on the other hand, that it is not up to first philosophy to clarify the principles of the special sciences: this would go against the autonomy of the special sciences claimed in the Posterior Analytics, where it is stated that the principles specific to each science are not demonstrable. According to Berti, therefore, the

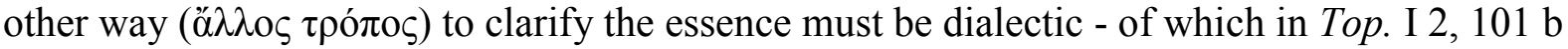
2-4 it is said that gives access to the principles of all methods - or the intellect (voṽs), that in

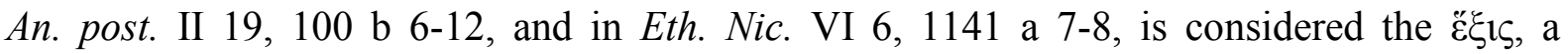
disposition or possession of the principles. The scholar says that the two interpretations could come together if we accept that dialectic introduce us to the intellect. ${ }^{61}$ On the other hand, while Aristotle undeniably rules out the possibility of demonstrating the principles (in the

${ }^{54} \mathrm{Cf}$. Movia, Introduzione, p. LXXXII and note 18.

${ }^{55}$ Cf. pseudo-Alexander, In Metaph., pp. 441, 38-442, 1.

${ }^{56} \mathrm{Cf}$. Aristotle, An. post. I 31, 87 b 28-39. Cf. Movia, Introduzione, p. LXXXIII.

${ }^{57}$ Cf. Aristotle, An. post. I 18, 81 a 39-b 1. Cf. Movia, Introduzione, p. LXXXIII.

${ }^{58}$ Cf. pseudo-Alexander, In Metaph., p. 442, 1-5.

${ }^{59} \mathrm{Cf}$. Movia, Introduzione, p. LXXXIII and note 22.

${ }^{60} \mathrm{Cf}$. Movia, Introduzione, p. LXIII.

${ }^{61}$ Cf. Aristotle, An. post. I 3, 72 b 18-25. Cf. Berti, Métaphysique, pp. 89-90. 
strict sense) - not only for the special sciences, but also for first philosophy - given that the principle is intrinsically not demonstrable, the feasibility of intellect or dialectic being the other way to clarify the essence remains problematic. We know that the only form of demonstration that Aristotle accepts for the principle of non-contradiction, and for the principle of excluded middle, is by refutation, as discussed in Metaph. $\Gamma$, and only first philosophy can provide this particular demonstration. Assigning this task to another science, or to another method, raises the difficulty of explaining the whole of Book $\Gamma$. Asclepius also says clearly that the essence is not demonstrable, and he gives the example of mathematics, which does not demonstrate its objects, but it assumes their existence by hypothesis. ${ }^{62}$

The last reason for the distinction between first philosophy and special sciences lies in that the latter do not say whether or not the class of being on which they focus exists, since the rational procedure that leads to the essence of a thing is the same as the one that leads to knowledge of the existence of a thing. In other words, we can only wonder what object we are dealing with if we know that it exists. ${ }^{63}$ While the special sciences are unable to explain either the essence or the existence of the object on which they focus, philosophy is capable of doing both. It explains the essence and the existence of its object, i.e. of being qua being, distinguishing between its meanings, that is categories, demonstrating that the first of these is the substance, and indicating its principles. ${ }^{64}$ Pseudo-Alexander again uses the example of medicine, saying that it does not demonstrate the essence of fire, nor does it consider whether man - its object - exists or not. This happens because it would only be possible to demonstrate that man exists if it were possible to demonstrate that man is a 'terrestrial biped animal'. Since it is impossible to demonstrate this definition ${ }^{65}$, it is likewise impossible to demonstrate that man exists. ${ }^{66}$

Aristotle then proceeds to show that physical science is one of the theoretical sciences, the goal of which is knowledge of the truth. ${ }^{67}$ He says that physics is concerned with a particular genus of being, i.e. the substance that has the principle of its movement and rest

${ }^{62}$ Cf. Asclepius, In Metaph., p. 360, 1-10.

${ }^{63}$ Cf. Aristotle, Metaph. E 1, 1025 b 16-18. Cf. Aristotle, An. post. II 1, 89 b 34-35.

${ }^{64} \mathrm{Cf}$. Movia, Introduzione, p. LXXXIV and note 28.

${ }^{65}$ On this issue pseudo-Alexander rightly refers to the Posterior Analytics (cf. Aristotle, An. post. II 8, 93 a 3-15; 93 b 15-20). Cf. Mario Mignucci, L'argomentazione dimostrativa in Aristotele. Commento agli Analitici secondi, vol. I (Padova; Antenore 1975), p. 331. Cf. Movia, Introduzione, p. LXXXIV and note 30 .

${ }^{66}$ Cf. pseudo-Alexander, In Metaph., p. 442, 5-12.

${ }^{67}$ Aristotle, Metaph. $\alpha$ 1, 993 b 20-21. 
present in itself. So physics can be neither a productive science (since the principle of productions is in what it produces, and this is either intellect or art, or some other faculty), nor a practical science (because the principle of the action lies in the agent, and is the disposition; in fact, the object of the action and of the disposition coincide).$^{68}$ On the matter of natural bodies - the object of physical science - pseudo-Alexander poses the problem of how the celestial bodies can be considered as such, given that they do not seem to possess the principle of rest, being endowed with circular and eternal movement. The commentator adds, however, that their revolving around the same point, and never changing place equates to being in a state of rest, or remaining immovable. ${ }^{69}$ This explanation goes along with Aristotle's view that every planet is carried by a sphere that moves in a circle, and therefore constantly around the same points. ${ }^{70}$ Then pseudo-Alexander says that, insofar as philosophy studies being qua being, and seeks its principles, and bearing in mind that to understand being qua being is to have the ability to clarify the essence of things, we clearly also need to search for the essence. ${ }^{71}$ In agreement with Movia, it is important to specify that the commentator means not that philosophy should explain the essence of natural entities, but that it should search for the essence of a being considered qua being. It should try to establish what makes a given being that particular being or, in other words, to seek its primary causes. $^{72}$ As an example of practical science, pseudo-Alexander mentions dancing, making the very acute observation that, after dancing, nothing remains. ${ }^{73}$ While it is true that Aristotle would classify the art of dancing as a productive science ${ }^{74}$, the observation that nothing remains afterwards recalls the knowledge and the pleasure that Aristotle admits arise from the fine arts, which brings them closer to the theoretical sciences. ${ }^{75}$

In pseudo-Philoponus's commentary, physics is defined as a 'contemplative, not active science ${ }^{76}$, underscoring the rational, speculative nature of the theoretical sciences vis-à-vis the practical and productive sciences. Inasmuch as it is research and investigation, Aristotle's

\footnotetext{
${ }^{68}$ Cf. Aristotle, Metaph. E 1, 1025 b 18-24.

${ }^{69}$ Cf. pseudo-Alexander, In Metaph., p. 442, 29-35.

${ }^{70} \mathrm{Cf}$. Aristotle, De caelo II 8, 289 b 1-290 a 35.

${ }^{71}$ Cf. pseudo-Alexander, In Metaph., p. 443, 1-6.

${ }^{72} \mathrm{Cf}$. Movia, Introduzione, p. LXXXV.

${ }^{73}$ Cf. pseudo-Alexander, In Metaph., p. 443, 38.

${ }^{74}$ Cf. Aristotle, Poet. 1, 1447 a 16, 26 28; 4, 1448 b 4-17.

${ }^{75} \mathrm{Cf}$. Movia, Introduzione, p. LXXXV.

${ }^{76}$ Cf. pseudo-Philoponus, In Metaph., p. 24 r.
} 
$\theta \varepsilon \omega$ pí $\alpha$ should not be envisaged as an acritical attitude to reality. It is worth noting another similarity between the commentaries of pseudo-Philoponus and pseudo-Alexander: in both cases, Aristotle's claim that physics is a theoretical science is interpreted as the conclusion of a syllogism, that the two authors describe in almost exactly the same terms. ${ }^{77}$ Aristotle justifies the classification of physics as a theoretical science by saying that this science must involve knowledge about such being as admits of being moved, and about substance in the

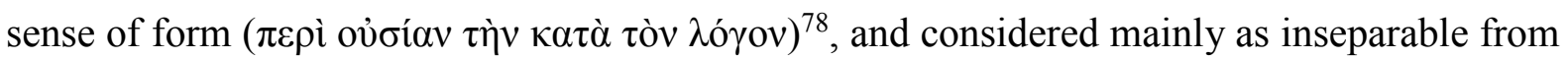
matter. ${ }^{79}$ Pseudo-Alexander interprets the passage in the sense that:

physics considers the material substance, but only to a lesser degree, while it is concerned to a greater degree and for the most part with the substance according to the definition and form. Having said that for the most part it studies the substance according to the definition, and having added "not only separable", [Arist.] seems to mean that this science is not only concerned with the separate, but also with the inseparable form. He does not mean to say, however, that it is concerned with both the separable and the inseparable, but he says 'not only separable' instead of 'only not separable'. In other words, he <affirms $>$ that this science only concerns the inseparable substance, that cannot be separated from matter. ${ }^{80}$

According to the commentator, the object of physics would be partly the material substance, but to a greater degree the substance considered according to the definition ( $\lambda$ ó $\gamma \circ \varsigma$ )

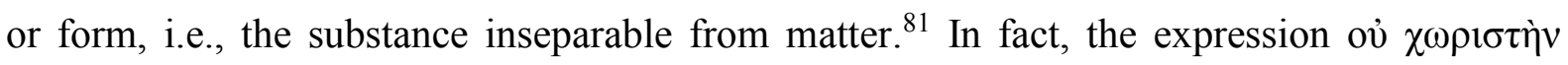

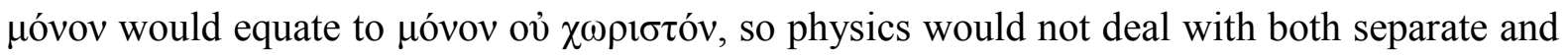
inseparable substances. The object of physics would consist in forms exhibited in definitions

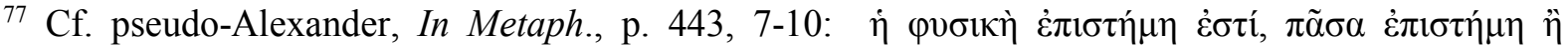

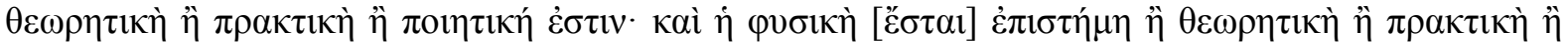

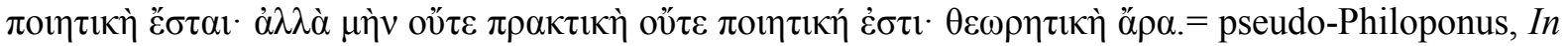
Metaph., p. 24 r: Physica, scientia est; omnis scientia vel contemplativa, vel activa, vel factiva est. Et physica ergo vel contemplativa, vel activa, vel factiva erit. Sed enim, neque activa, neque factiva est [...] contemplativa ergo erit.

${ }^{78}$ The expression has been interpreted in various ways. On this issue, see Norma Cauli, Commento al libro E (sesto). Presentazione, traduzione e note, in Movia, Commentario alla "Metafisica", pp. 11291191, spec. p. 1182 note 70.

${ }^{79}$ Cf. Aristotle, Metaph. E 1, 1025 b 25-28.

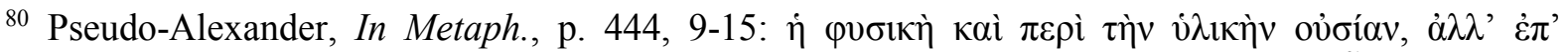

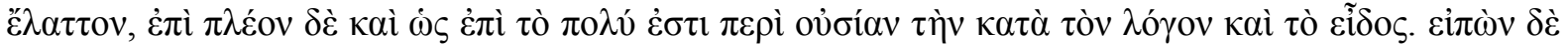

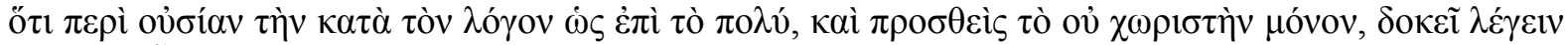

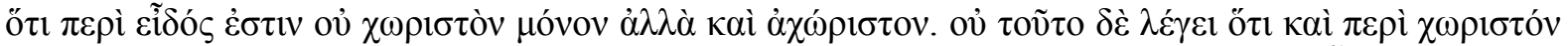

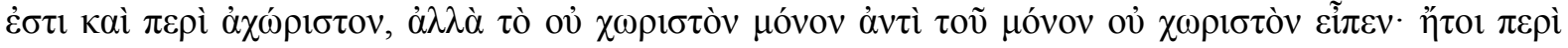

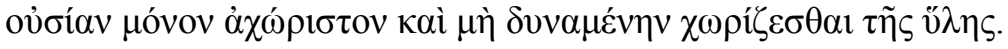

${ }^{81}$ So also Bonitz (cf. Aristoteles, Metaphysik, übersetzt Hermann Bonitz, neu bearbeitet, mit Einleitung und Kommentar, hrsg. v. Horst Seidl, griechischer Text in der Edition von Wilhelm Christ, Hamburg 1978, Bd. 1, pp. 282-283); Jules Tricot, Aristote, La Metaphysique, nouvelle éd. entièrement refondue avec commentaire (Paris, Vrin 1962), vol. I, p. 330 and note 1. 
- in which matter appears too, however. ${ }^{82}$ Asclepius comments on Aristotle's claim that physics $^{83}$ is concerned with such genus of being as has the principle of its movement and rest present in itself ${ }^{84}$, and specifies that first philosophy deals with immovable substances. He also emphasizes that physics is concerned with material forms ${ }^{85}$, whereas first philosophy focuses not on natural and moving entities, but only on immaterial and immovable substances. Since these substances are the principles of all things, however, first philosophy will focus on all entities. ${ }^{86}$

Aristotle reiterates and clarifies this point immediately afterwards, when he says that physics is concerned with substance as defined for the most part only as not separable from matter. This rules out the mathematical entities (e.g. the snub), which are defined in relation to intelligible matter and not to sensible matter, and also the rational soul, which might possibly exist independently of the body. ${ }^{87}$ Going against the Platonics, pseudo-Alexander claims that a natural form cannot exist per se, separate from matter. ${ }^{88} \mathrm{~A}$ little later on, referring to Aristotle's example of the snub ${ }^{89}$, he says it is impossible to define natural forms separately from matter. Referring to Metaph. Z 12, 1037 b 27-32, the commentator states that by 'matter' of the definition of natural entities we must therefore mean the genus and the differences preceding the ultimate difference. ${ }^{90}$ Pseudo-Alexander subsequently identifies matter with movement ${ }^{91}$, while for Aristotle movement is a property of the matter of sensible entities. ${ }^{92}$ As for the comment in Asclepius on 1025 b 28-30, it is worth emphasizing that the

${ }^{82} \mathrm{Cf}$. Movia, Introduzione, p. LXXXVI and note 42. The same was true of Bonitz (cf. Metaph., pp. 282-283); Tricot, Metaph., I, p. 330 and n. 1. Cf. Norma Cauli, in Movia, Commentario alla "Metafisica", p. 1182 note 70.

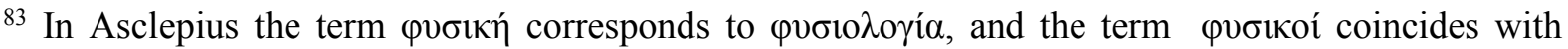

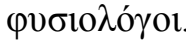

${ }^{84}$ Cf. Aristotle, Metaph. E 1, 1025 b 26-27.

${ }^{85}$ Cf. Asclepius, In Metaph., p. 360, 25-27. Thus Tricot, Metaph., I, p. 330 note 1; Giovanni Reale, Introduzione, traduzione e commentario alla Metafisica di Aristotele (Milano, Bompiani 2004), pp. 977-978 note 9.

${ }^{86}$ Cf. Asclepius, In Metaph., p. 361, 26-32. Cf. Klaus Kremer, Der Metaphysikbegriff in den Aristoteles-Kommentaren der Ammonius-Schule (Münster, Aschendorff 1961), pp. 40-44.

${ }^{87}$ Cf. Aristotle, Metaph. E 1, 1025 b 28-1026 a 6. Cf. Movia, Introduzione, p. LXXXVI.

${ }^{88}$ Cf. pseudo-Alexander, In Metaph., p. 444, 25-27. Cf. Movia, Introduzione, p. LXXXVI.

${ }^{89}$ Cf. Aristotle, Metaph. E 1, 1025 b 34-1026 b 5.

${ }^{90}$ Cf. pseudo-Alexander, In Metaph., p. 444, 30-33. Cf. Movia, Introduzione, p. LXXXVI.

${ }^{91}$ Cf. pseudo-Alexander, In Metaph., p. 445, 8-9. Cf. Movia, Introduzione, p. LXXXVI.

${ }^{92}$ Cf. Aristotle, Metaph. H 1, 1042 b 5-6. Cf. Movia, Introduzione, p. LXXXVI. 
commentator believes physics must be concerned with material forms and their differences: we cannot simply say of the form $(\sigma \chi \eta \mu \alpha)$ of the hand that it is such a thing (i.e. that it is

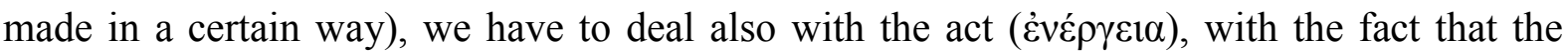
hand is designed to grasp and throw, for instance. ${ }^{93}$ Asclepius therefore sees the differences that, together with the form, define an entity in terms of the act of the entity, the action that characterizes it and distinguishes it from other things.

Aristotle moves on to deal with the second theoretical or dianoetic science ${ }^{94}$ mathematics - and makes the point that it is still not clear whether it is a science of immovable and separate beings, even though some parts of mathematics clearly consider their objects as immovable and separate. ${ }^{95}$ Pseudo-Alexander explains this passage with a syllogism that appears in a virtually identical form in pseudo-Philoponus's commentary too. ${ }^{96}$ The difference between the theoretical sciences is explained as follows:

Cum discreverit physicam a mathematica, nunc discernit primam philosophiam a mathematica et a physica, et duos texit syllogismos. Physica circa inseparabilia et mobilia, prima philosophia circa separata et immobilia, et rursus. Mathematica circa immobilia quaedam, sed non etiam inseparabilia. Prima vero philosophia, et circa immobilia et circa separata est. ${ }^{97}$

On this topic we have to agree with Klaus Kremer, when he points out that, in 1026 a 14 (unlike $1025 \mathrm{~b} 28$, where he claims that the object of physics is ov $\chi \omega \rho ı \tau$ óv), Aristotle would be saying that the object of physics would be $\chi \omega \rho ı \tau$ óv, that in this case would indicate the substantial being. According to Kremer, physics would deal with entities that can exist per se, in contrast with mathematical entities that, being accidents, are oủк $\chi \omega \rho ı \tau$ á. PseudoPhiloponus (who Kremer believes to be the authentic Philoponus) would interpret the Aristotelian term $\chi \omega \rho ı \sigma \tau o ́ v$ in the sense of abstraction. ${ }^{98}$ Pseudo-Alexander reads $\tilde{\eta} \chi \chi \omega \rho ı \tau \alpha ́$

${ }^{93}$ Cf. Asclepius, In Metaph., p. 361, 8-12. This point of view is repeated, particularly in 361, 19-20.

${ }^{94}$ Cf. Aristotle, Metaph. E 1, 1025 b 25.

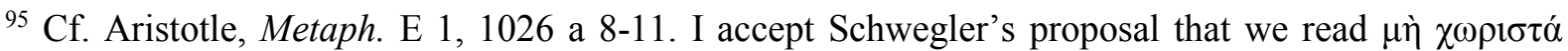
instead of $\tilde{\eta} \chi \omega \rho \iota \sigma \tau \dot{~}$ on lines 9-10. Cf. Albert Schwegler, Die Metaphysik des Aristoteles, Grundtext, Übersetzung und Commentar, nebst Erläuternden Abhandlungen, Bd. 4 (Frankfurt am Main, Minerva 1960), pp. 14-16; Movia, following Ross, Metaph., vol. I, p. 355, believes instead that Aristotle is referring to pure mathematics as separable with thought from matter (cf. Movia, Introduzione, pp. LXXXVI-LXXXVII).

${ }^{96}$ Pseudo-Alexander, In Metaph., pp. 445, 22-24 i்

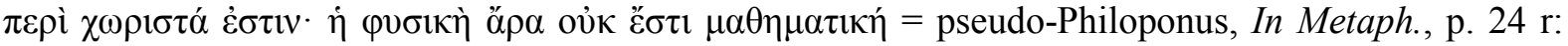
Mathematica dianoetica existens, circa immobilia et separata est. Physica, dianoetica cum sit, neque circa immobilia, neque circa separata est. Physica ergo mathematica non est.

${ }^{97}$ Pseudo-Philoponus, In Metaph., p. $24 \mathrm{r}$ f.

${ }^{98}$ Cf. Kremer, Metaphysikbegriff, p. 68 note 244. 
in 1026 a $9-10^{99}$, and seems to be referring to pure mathematics when he speaks of «some objects inasmuch as they are immovable and inasmuch as they are separate» (probably meaning numbers and quantities). ${ }^{100}$

Aristotle finally says that, if it is true that something eternal, immovable and separate exists, it must be the object of a theoretical science - not physics (since this is concerned with entities in motion), or mathematics, but a science that is prior to them. In fact, physics studies realities that are not separate ${ }^{101}$ and not immovable, and some mathematics concerns realities that are immovable and not separate, but immanent to matter, whereas separate and immovable substances are the object of first philosophy. ${ }^{102}$ Pseudo-Alexander makes the point that, if an eternal, immovable and separate entity exists, it must be the cause of other things. ${ }^{103} \mathrm{He}$ interprets Aristotle's claim that it is necessary for all causes to be eternal ${ }^{104}$ in the sense that, if every cause were generated, the series of causes would go on to infinity. ${ }^{105}$ The same explanation can be found in Asclepius. ${ }^{106}$ Aristotle goes on to say that the immovable and separate realities forming the object of first philosophy must, above all, be divine, since «they are the causes of the divine as appears to us». ${ }^{107}$ Pseudo-Alexander describes this last expression as «more obscure because of the brevity of the discourse» ${ }^{108}$, and he interprets it as meaning that the immovable and separate entities would be the causes of the divine entities, i.e. of the spheres and of the divine bodies, the unmoved movers, which would be the cause behind the fact that the bodies that we see are generated and destroyed ${ }^{109}$. Asclepius ${ }^{110}$ and pseudo-Philoponus ${ }^{111}$ also identify the eternal causes with the unmoved

${ }^{99}$ So also Asclepius (cf. Asclepius, In Metaph., p. 363, 7-8).

${ }^{100}$ Cf. pseudo-Alexander, In Metaph., p. 445, 31. Cf. Movia, Introduzione, p. XXXVII.

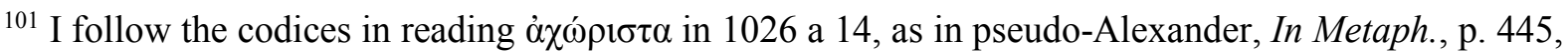
38; Asclepius, In Metaph., p. 363, 18, while Schwegler and the other modern editors of the Metaphysics (except for Bekker and Bonitz) correct the term to read $\chi \omega \rho ı \sigma \tau \alpha$.

${ }^{102}$ Cf. Aristotle, Metaph. E 1, 1026 a 10-16.

${ }^{103}$ Cf. pseudo-Alexander, In Metaph., p. 446, 11-12. Cf. Movia, Introduzione, p. LXXXVII.

${ }^{104}$ Cf. Aristotle, Metaph. E 1, 1026 a 16-17.

${ }^{105}$ Cf. pseudo-Alexander, In Metaph., p. 446, 12-13. Cf. Movia, Introduzione, p. LXXXVII.

${ }^{106}$ Cf. Asclepius, In Metaph., p. 363, 27-29.

${ }^{107}$ Cf. Aristotle, Metaph. E 1, 1026 a 17-18.

${ }^{108}$ Cf. pseudo-Alexander, In Metaph., p. 446, 16-17.

${ }^{109}$ Cf. pseudo-Alexander, In Metaph., p. 446, 17-20.

${ }^{110}$ Cf. Asclepius, In Metaph., p. 363, 29-30.

${ }^{111}$ Cf. pseudo-Philoponus, In Metaph., p. 24 v. 
movers of the skies, consistently with the theologizing interpretation of Aristotle's metaphysics.

In the final part of the chapter, Aristotle states that there are three branches of theoretical philosophy - mathematics, physics and theology. At the top, Aristotle places theological science, which investigates the highest object of reality, and that is why it can be called 'theological'. ${ }^{112}$ Pseudo-Alexander says that, if the divine is the thing most worthy of honor, then - of all the sciences - theology must be the science most worthy of honor ( $\tau \mu \iota \omega \tau \alpha \dot{\tau} \tau)$. It will be concerned with the divine genus of reality, and it will be the most highly esteemed science, that has as its object what there is of greatest value. ${ }^{113}$ Asclepius describes theological science in the same terms. ${ }^{114}$ The chapter ends with one of Aristotle's most problematic and often discussed passages: the aporia that poses the problem of whether first philosophy is the science of being qua being, and therefore universal, or whether it is a special science coinciding with theology, which has immovable and separate substances as its object. Aristotle offers the example of mathematics, where geometry and astronomy concern a given reality, while general mathematics is common to all realities. If no other substance existed beyond the natural substances, then physics would be the first science. But if an immovable substance exists, this will be prior ( $\pi \rho \circ \tau \varepsilon \dot{\varepsilon} \rho)$, and first philosophy will be the first science, and it will be universal specifically because it is the first. This science would be concerned with the being qua being, or in other words with what being is and the properties it possesses. $^{115}$

Pseudo-Alexander explains that Aristotle's suggested alternative consists in examining whether first philosophy is universal, and thus includes and stands above all the sciences (just as particulars come under the universal), or whether it is not universal, but like medicine and astronomy, which delimit and are concerned with a certain part of being. ${ }^{116}$ PseudoAlexander rightly goes on to rule out the possibility of first philosophy and the special sciences being related like genus to species, as in the relationship between universal mathematics and special mathematics. The commentator follows Aristotle's text, making the primacy of first philosophy depend on its object, which is the immovable and separate

\footnotetext{
${ }^{112}$ Cf. Aristotle, Metaph. E 1, 1026 a 18-23. Cf. Movia, Introduzione, p. LXXXVII.

${ }^{113}$ Cf. pseudo-Alexander, In Metaph., pp. 446, 35-447, 7. Cf. Movia, Introduzione, p. LXXXVII.

${ }^{114}$ Cf. Asclepius, In Metaph., p. 364, 1-3.

${ }^{115}$ Cf. Aristotle, Metaph. E 1, 1026 a 23-32. Cf. Movia, Introduzione, p. LXXXVII.

${ }^{116}$ Cf. pseudo-Alexander, In Metaph., p. 447, 9-14.
} 
substance, or the first substance. He explains that the universal character of first philosophy should be intended as meaning not that this science includes the others, but in the sense of what is most worthy of honor, and pseudo-Philoponus takes the same view. ${ }^{117}$ PseudoAlexander does not clarify the identification of first philosophy with the science of being qua being, however. ${ }^{118}$ Asclepius says that the first science is universal specifically because it is the first, that is because it has in itself the principles of all things. That is why this science is concerned with being simply ( $\dot{\alpha} \pi \lambda \tilde{\omega} \varsigma)$ and it explains that this means God, who provides for all things and, strictly speaking, has no privations. ${ }^{119}$ We read in pseudo-Philoponus's commentary that, if an immovable and separate substance exists, the universal science will not be physics, but the science concerned with contemplating (contemplari) being qua being. ${ }^{120}$ His use of the verb contemplari again denotes the speculative nature of first philosophy, clearly distinct from that of practical philosophy or productive philosophy.

According to Movia, Aristotle's solution to the aporia would lie in that, for there to be a science of being qua being, which is the broadest of all objects, we need to seek the primary causes. But, since the primary causes are the most universal, the science of primary causes must be the most universal science. Now, the primary cause of entities, in the order of efficient causality, is the immovable substance. As a consequence, the science that has as its object the immovable substance or 'theology', inasmuch as it is the first science, is one and the same as the science of being qua being, or 'ontology'. ${ }^{121}$ In fact, the alternative Aristotle suggests in his formulation of the aporia in 1026 a 23-24 concerns the universality of metaphysics as opposed to its identification with a particular science, so this is the same alternative as the one in Metaph. $\Gamma 1$, between the science of being qua being and the special sciences. The solution to the aporia - which rules out the particular nature of first philosophy being due simply to it coming 'first' inasmuch as it is the science of the immovable substance - would therefore seem to indicate that the science of being qua being fully coincides with the

${ }^{117}$ Cf. pseudo-Philoponus, In Metaph., p. 24 v.

${ }^{118}$ Cf. pseudo-Philoponus, In Metaph., p. 447, 19-36. Cf. Movia, Introduzione, p. LXXXVIII, where it is also rightly said that pseudo-Alexander's failure to explain the relationship of identity that links the science of being qua being with the science of the primary substance marks a step back vis-à-vis the authentic Alexander, who clearly bears his mind the role in this context of the concept of cause (cf. Alex. In Metaph., p. 246, 10-13; but see also pseudo-Alexander, In Metaph., p. 446, 11-12).

${ }^{119}$ Cf. Asclepius, In Metaph., p. 364, 24-27.

${ }^{120}$ Cf. pseudo-Philoponus, In Metaph., p. 24 v.

${ }^{121}$ Cf. Movia, Introduzione, p. LXXXVIII and note 58. The reduction of ontology to theology is accepted by Kirwan, Metaphysics, pp. 188-189, but rejected by Berti, Métaphysique, pp. 127-128. 
science having as its object the immovable substance. This conclusive passage in chapter I, and the primacy of theology over the other sciences are two of the fundamental passages prompting the conception of Aristotle's metaphysics as a theological science. A further passage - this time with a negative sense, as we shall see - can be found in his subsequent discussion of the meanings of being, and particularly of accidental being.

\section{Accidental being}

In the second chapter of Book E Aristotle discusses the four meanings of unqualified term 'being': (1) accidental being; (2) being as truth and not-being as falsity; (3) the figures of predication; and (4) being potentially and actually. His use of the imperfect tense $\tilde{\eta} v$ in 1026 a 34 to indicate accidental being leads us to believe that he was referring to an earlier work. ${ }^{122}$ The ancient commentators do not refer us to any previous work, however, with the exception of pseudo-Alexander, who simply recalls that this issue has already been discussed. ${ }^{123}$ Modern scholars believe the reference is to Book $\Delta$ of the Metaphysics. ${ }^{124}$ Pseudo-Alexander justifies the subsequent treatment of accidental being, and of being as truth and not-being as falsity already in a comment on this passage in Aristotle. The commentator says we must start by assuming that there can be no science of accidental being because theological science comes before the other sciences, and it only studies being qua being and its properties. ${ }^{125}$ To the commentators, the result that Aristotle reaches will seem, in a sense, rather like a negation that excludes certain meanings of being from scientific inquiry, thereby also placing them beyond the object of metaphysics. The subsequent chapters in Book E are consequently seen as serving the purpose of demonstrating what should be excluded from the sphere of first philosophy proper.

To explain accidental being, pseudo-Alexander says that, while the sculptor is a per se cause of the statue, Polyclitus accidentally causes it because Polyclitus happens to be sculptor. In actual fact, since Polyclitus is a sculptor, Aristotle would say that he is a per se cause of the statue. Then the commentator takes an example of being as truth concerning Socrates, of whom - when he is seated - it is true to say that he is seated, that is, he is said to

\footnotetext{
${ }^{122}$ Cf. Aristotle, Metaph. E 2, 1026 a 33-b 2.

${ }^{123}$ Cf. pseudo-Alexander, In Metaph., p. 448, 2: Eip $\eta \tau \alpha 1$.

${ }^{124}$ Cf. Bonitz, Ross, Tricot, Kirwan, Reale. For further details, see Berti, Métaphysique, pp. 134-136.

${ }^{125}$ Cf. pseudo-Alexander, In Metaph., pp. 447, 38-448, 15.
} 
be. Following Aristotle's text, pseudo-Alexander gives an example of the figures of predication, considering the first category: the essence, i.e. the substance ${ }^{126}$, and therefore quantity and quality. Finally, as concerns being potentially and actually, the commentator quotes the case of water, which is actually water, and of air and fire, which are potentially water because they can become water. ${ }^{127}$ Asclepius also provides examples of the four meanings of being. Accidental being is explained with the case of the bald house-builder, who does not build because he is bald, but because he is a builder. For being as truth and notbeing as falsity, he uses the example of Socrates, of whom it is true to say that he is Socrates if it is really him, and if not it is false. On the concept of the figures of predication, i.e. of being per se, Asclepius speaks of the essence, quality and quantity, and mentions man, magnitude, and white, respectively, as examples of them. As for being potentially and actually, he gives the example of sperm, which is potentially a child, and what it has become. ${ }^{128}$

Aristotle begins by dealing with accidental being and shows that there is no science of it. As proof ( $\sigma \eta \mu \varepsilon i ̃ v)$ of this, he mentions the fact that none of the sciences - be they practical, productive, or theoretical - are concerned with accidents. He refers to architectural science, which causes the house, but is not responsible for the accidental properties that the house will come to have, which are infinite: some will find the house pleasant, some will judge it hurtful, to others it will seem useful and - Aristotle adds - different from all other things. ${ }^{129}$ Asclepius ignores this addition, whereas pseudo-Alexander mentions it, and says that nobody is concerned with whether the house as built is different from or identical to man, or whether it differs from all sensitive and intelligible beings. ${ }^{130}$ A similar explanation can be found in pseudo-Philoponus, which goes to show yet again that he draws on pseudoAlexander's commentary. ${ }^{131}$ The same examples can also be found in the two works relating

${ }^{126}$ Cf. Mignucci, L'argomentazione, vol. I, p. 532, where we find that $\tau$ í in 1026 a 6 equates to the category of substance. Cf. Cauli, in Movia, Commentario alla "Metafisica", p. 1184 note 122.

127 Cf. pseudo-Alexander, In Metaph., p. 448, 2-13. In fact, Aristotle accepts the reciprocal transformation of the elements. Cf. Aristotle, De gen. et corr. II 4.

${ }^{128}$ Cf. Asclepius, In Metaph., p. 364, 30-365,6.

${ }^{129}$ Cf. Aristotle, Metaph. E 2, 1026 b 2-10.

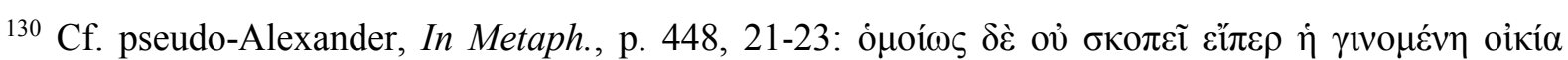

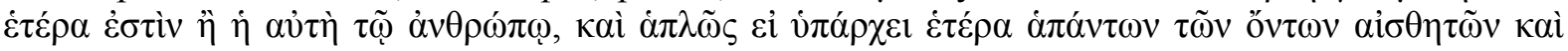

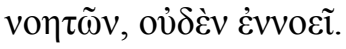

${ }^{131}$ Cf. pseudo-Philoponus, In Metaph., p. 24 v: Similiter neque de eodem considerat et altero circa domum. Si quidem quae fit domus eadem est, vel alteri homini, vel animali. 
to 1026 b 7-8: pseudo-Alexander says that no architect will wonder whether the house is good for Socrates or whether it is unhealthy for Plato, pleasant for Theophrastus, or unhealthy for Alexander. In pseudo-Philoponus, we find the passage repeated almost word for word, apart from the inversion of the names of Socrates and Plato. ${ }^{132}$

Having used the example of architecture (which is a productive science), Aristotle claims that geometry (which is a theoretical science) likewise does not study the accident of its objects, i.e. figures. It is not concerned, for instance, with the question of whether there is a difference between a triangle and a triangle having its angles equating to two right angles. ${ }^{133}$ Asclepius explains Aristotle's passage with the example of the geometer, who is not concerned with whether triangles are on the right or left. He only studies the properties that belong per se to the figures, such as - in the case of triangles - the property of having its angles equating to two right angles. ${ }^{134}$ So, what Aristotle sees as a matter of no concern to the geometer becomes quite the opposite in Asclepius, an example of what the geometer studies. A little later on, Asclepius adds that the geometer is not concerned with the question of whether the triangle is made of silver, bronze, or any other material. ${ }^{135}$ Pseudo-Alexander explains, probably on the strength of this passage ${ }^{136}$, that the geometer is not interested in whether figures are made of wood or stone, and accuses Aristotle of having incompletely formulated the example of the triangle. According to pseudo-Alexander, the wording of the phrase should have implied the expression «wooden», or something similar, so the meaning would have been ${ }^{137}$ : «nor is he concerned with establishing whether a wooden triangle is different from a triangle as such, and what its nature might be, in the sense of whether its angles equal two right angles, but he is only interested in whether the three angles of every triangle always equal two right angles»». ${ }^{138}$ By adding that the geometer does not consider whether the triangles are made of stone or wood, pseudo-Alexander shows that he believes

${ }^{132}$ Cf. pseudo-Philoponus, In Metaph., p. 24 v: Vel quia, Socrati verbi causa, conferet, Platoni autem non conferet. Vel Theophrasto quidem iucunda, Alexandro autem molesta = pseudo-Alexander, In

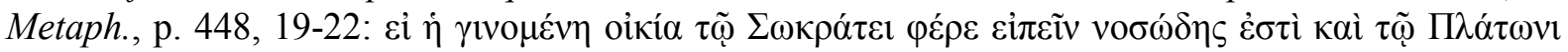

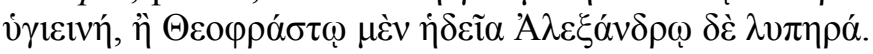

${ }^{133}$ Cf. Aristotle, Metaph. E 2, 1026 b 10-12.

${ }^{134}$ Cf. Asclepius, In Metaph., p. 365, 12-17.

${ }^{135}$ Cf. Asclepius, In Metaph., p. 366, 2-3.

${ }^{136}$ Cf. Berti, Métaphysique, p. 140.

${ }^{137}$ Cf. pseudo-Alexander, In Metaph., p. 448, 27-31.

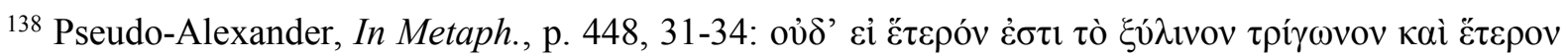

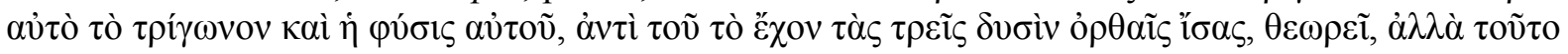

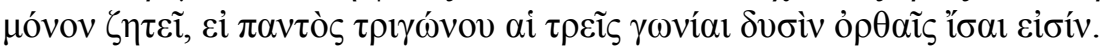


the accidental properties of the triangle consist not in having angles that equal two right angles, but in being made of stone or wood. The same view can be found in pseudoPhiloponus. ${ }^{139}$ Schwegler ${ }^{140}$ and Bonitz ${ }^{141}$ consider pseudo-Alexander's interpretation feasible, but both say that such an interpretation would be inconsistent with what Aristotle says in Metaph. $\Delta 30,1025$ a 32 about the property of a triangle with its angles equating to two right angles being an accident, albeit per se. Pseudo-Alexander's comment was also rejected by Ross, who rightly said that the sense of Aristotle's passage is that the geometer does not wonder whether the triangle as such, i.e. considered simply as a figure made of straight lines with three angles, is the same thing as the triangle considered as having its angles corresponding to two right angles. According to Ross, Aristotle wants to give an example of 'accidental being', such that the accident of the triangle that is of no interest to the geometer is not that of the triangle 'having its angles equal to two right angles', but that of the triangle 'being the same as, or different from the triangle that has angles equal to two right angles'. ${ }^{142}$ In fact, we have to assume that Aristotle's example concerns 'accidental being', and not just the accidental properties of the triangle. The sense of the passage thus seems to be that the geometer is not concerned with establishing whether the triangle as such differs from the triangle having angles equal to two right angles, just as the architect is not concerned with whether the house as such differs from the house inasmuch as it has certain characteristics.

Referring to the architect's and geometer's lack of interest in the accidental being, Aristotle says this happens for a good reason since the accident is like a name. ${ }^{143}$ Asclepius ${ }^{144}$

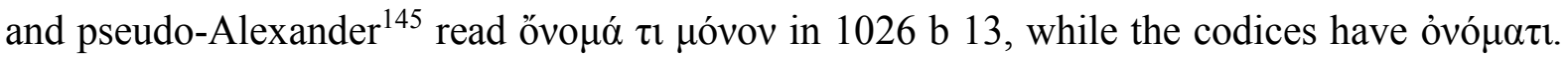
According to Asclepius, the formula means that accidental being has no stable and autonomous existence, but has its being in other things, and it is in what accompanies it $(\pi \alpha \rho \alpha \kappa о \lambda о v \theta \theta \eta \mu \alpha) .{ }^{146}$ Pseudo-Alexander suggests that accidentally being is like the

${ }^{139}$ Cf. pseudo-Philoponus, In Metaph., p. 24 v: Geometra, considerat ea quae secundum accidens insunt figuris, si ligneus est cubus, vel aereus triangulus.

${ }^{140}$ Cf. Schwegler, Metaphysik, Bd. 4, p. 21.

${ }^{141}$ Cf. Bonitz, Metaph., p. 287.

${ }^{142}$ Ross, Metaph., vol. I, p. 358.

${ }^{143}$ Cf. Aristotle, Metaph. E 2, 1026 b 13-14.

${ }^{144}$ Cf. Asclepius, In Metaph., p. 365, 21-22.

${ }^{145}$ Cf. pseudo-Alexander, In Metaph., p. 448, 36.

${ }^{146}$ Cf. Asclepius, In Metaph., p. 367, 21-23. 
hircocervus, which is by no means an object, a certain nature, or a kind of entity. The commentator adds that saying that a house is unhealthy or healthy is only giving it a name, it does not express a reality. If 'unhealthy' or 'healthy' were something substantial, then the house would be unhealthy or healthy for all those who enter it, whereas it happens that for some it is unhealthy and for others it is healthy. ${ }^{147}$ The example of the hircocervus can be found in pseudo-Philoponus too. ${ }^{148}$ Pseudo-Alexander should be acknowledged the merit for his conviction that Aristotle's discourse focused not on accident, but on accidental being. ${ }^{149}$

Asclepius introduces his comment on this section of Aristotle's text by saying that,

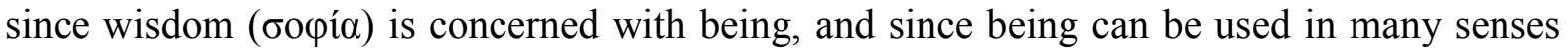
(i.e. being as truth, being potentially and actually, and being per se, including the ten categories), Aristotle would be saying that wisdom is concerned with all the meanings of being. The only exception ( $\chi \omega \rho i ́)$ ) is accidental being, since it is indeterminate, without cause, and impossible to bring down primarily to the God and nature ${ }^{150}$, i.e. to what is always, or for the most part. ${ }^{151}$ Here Asclepius goes beyond Aristotle, who actually says it is not for metaphysics to be concerned with being as truth and not-being as falsity either. But the commentator's statement fully justifies the discussion of accidental being in Book E: Aristotle wants to show that it should be excluded from the object of the first science - what is called 'wisdom' here, and the science of primary causes in Metaph. A, which is also the science most possessed by the $\operatorname{God}^{152}$, whereas accident is said to be 'without cause'.

Straight afterwards, Aristotle says this is the reason why Plato, in a sense rightly, considered Sophistry as the science of not-being. In fact, the Sophists' discussions - says Aristotle - focus mainly on accident. For instance, they pose the problem of whether 'musician' and 'grammarian', or 'Coriscus' or 'Coriscus the musician' are different or identical. The Sophists also wonder whether all that is, but that is not eternal, has come into being, and thus whether someone who is a musician has become a grammarian or whether, being a grammarian, he has become a musician, and other questions of this type. ${ }^{153}$ The

${ }^{147}$ Cf. pseudo-Alexander, In Metaph., p. 448, 35-449, 6.

${ }^{148}$ Cf. pseudo-Philoponus, In Metaph., p. 24 v. The same example can be found in Aristotle, De interpr., $16 \mathrm{a} 16$.

${ }^{149}$ Cf. pseudo-Alexander, In Metaph., pp. 448, 35-39; 449, 7.

${ }^{150}$ Cf. Asclepius, In Metaph., p. 365, 23-29.

${ }^{151}$ Cf. Aristotle, Metaph. E 2, 1026 b 28-33.

${ }^{152} \mathrm{Cf}$. Aristotle, Metaph. A 2, 983 a 6-10.

${ }^{153}$ Cf. Aristotle, Metaph. E 2, 1026 b 14-21. 
quotation from Plato sounds like a reference to the Sophist. On this issue, Asclepius mentions that Aristotle correctly says that Plato was right in a sense ( $\tau \rho o ́ \pi o v ~ \tau \imath v \alpha ́)$, since accidents have some sort of obscure existence. ${ }^{154}$ Pseudo-Alexander justifies the reference to Plato by saying that Sophistry deals with accidental being because it is only a name, not something that is ${ }^{155}$. So «Plato classifies it as an activity that focuses on not-being, in the sense that the accident is not-being». ${ }^{156}$ The same explanation can be found in pseudo-Philoponus. ${ }^{157}$

Asclepius writes that Aristotle's passage contains three paralogisms:

1) If, posed the question «Are musicians and grammarians identical or different?», we answer that musicians are different from grammarians, the Sophist will reply that they are in the same subject, for instance in Coriscus; if we answer that musicians and grammarians are identical, the Sophist will say that they are identical in different subjects, e.g. the musician is in Aristoxenus and the grammarian in Coriscus. In both cases, we are misled. According to Asclepius, we could answer that musician and grammarian are accidents of the same subject, and it is not impossible for them, though different, to belong to the same subject.

2) If, when asked the question «Are musician and Coriscus identical or different?», we answer that they are different, the Sophist will tell us that in that case Coriscus will differ from himself, since Coriscus is a musician; and if we answer that they are identical, the Sophist will say that Coriscus must therefore have come into being the moment he became a musician; both answers are clearly absurd. On the other hand, Asclepius suggests that our answer might be that Coriscus is no less Coriscus before and after becoming a musician: in fact, the accident may or may not come about without damaging the subject.

3) If, posed the question «Is Coriscus the musician a grammarian, or has he become a grammarian?», we answer that he is a grammarian, then the Sophist will reply that in that case Coriscus has always been a musician and a grammarian; if we say instead that Coriscus has become a grammarian, the Sophist will tell us that Coriscus has become a grammarian starting from being a musician and therefore, if everything that comes into being comes from not-being, the musician is not-being. Again both answers are absurd.

Asclepius claims that, against such paralogisms, we might say that the Sophist confuses absolute not-being with not-being in some way (being a musician, for instance). As a

\footnotetext{
${ }^{154}$ Cf. Asclepius, In Metaph., p. 366, 8-10.

${ }^{155}$ Cf. pseudo-Alexander, In Metaph., p. 449, 6-8.

${ }^{156}$ Cf. pseudo-Alexander, In Metaph., p. 449, 8-9.

${ }^{157}$ Cf. pseudo-Philoponus, In Metaph., p. 24 v: Ideo et Plato, circa non ens sophistica ordinavit, vel circa accidens.
} 
consequence, the commentator concludes, accidents are indefinite, they are causes of paralogisms, and - in a way - they are non-existent. ${ }^{158}$ For the purposes of what we intend to demonstrate here, it is emblematic that Asclepius should conclude his comment on this section by emphasizing that the aim of the discussion on accidental being is to demonstrate that it should be excluded from the object of wisdom ${ }^{159}$, while the reference to the other sciences is left unexplained.

Pseudo-Alexander writes that, posed the question «Are a grammarian and a musician identical or different?», if we answer that they are different, the Sophists will reply that Socrates is a grammarian, and that Socrates the grammarian is identical to Socrates. But Socrates is also a musician, so Socrates will be identical to Socrates the musician, and this means that Socrates the musician is identical to Socrates the grammarian - but then 'musician' will also be identical to 'grammarian'. The commentator goes on to say that, if 'musician' is different from 'grammarian', then Socrates the musician must be different from Socrates the grammarian, and therefore Socrates will be different from himself. According to pseudo-Alexander, the paralogism stems from the fact that 'musical-Socrates' and 'grammarian-Socrates' are and are not identical: they are identical inasmuch as concerns the

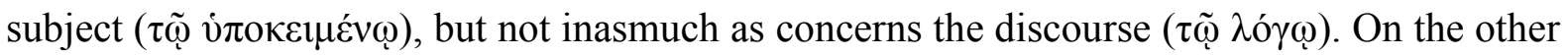
hand, if we answer the question «Are a grammarian and a musician identical or different?» by saying that 'musician' and 'grammarian' are identical, the Sophists will answer that, if that is the case, where there is a grammarian, there will also be a musician, but Aristarchus is a grammarian but not a musician, so a grammarian is not identical to a musician. ${ }^{160}$ The topic is covered in much the same way in pseudo-Philoponus's commentary. ${ }^{161}$

Aristotle moves on to say that the accidental is akin to not-being, as emerges from the following argument: beings that are in another way are generated and destroyed, while accidental beings give rise to no generation or destruction. ${ }^{162}$ Asclepius and pseudoAlexander interpret 1026 b 18-20 as another question formulated by the Sophists. ${ }^{163}$ Pseudo-

${ }^{158}$ Cf. Asclepius, In Metaph., pp. 366, 10-367, 17.

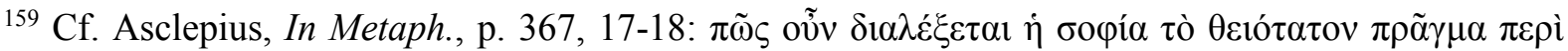

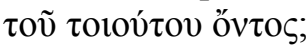

${ }^{160}$ Cf. pseudo-Alexander, In Metaph., p. 449, 11-27.

${ }^{161}$ Cf. pseudo-Philoponus, In Metaph., p. 24 v.

${ }^{162}$ Cf. Aristotle, Metaph. E 2, 1026 b 21-24.

${ }^{163}$ Cf. Asclepius, In Metaph., p. 367, 21-31; pseudo-Alexander, In Metaph., p. 450, 14-15. Cf. infra, § 3. 
Alexander explains that the Sophists wonder whether everything that exists now, and that once did not exist, has been generated. If a thing did not exist at first, and now it does, it must have been generated. This line of argument is applied to the previously-described paralogisms: if Coriscus, who was first a musician, is now a grammarian, then the musician has become a grammarian, and the grammarian had become a musician. So, if the Sophists pose questions of this kind, the accident is something similar to not-being. Pseudo-Alexander concludes by saying that, since accidental beings do not give rise to generation and destruction, they are non-entities, and he defers an explanation to his comment on E $3 .{ }^{164}$ Pseudo-Philoponus comments on this passage by noting that, if the accident were generated, then either the grammarian would be generated by the matter of the musician, like a statue from bronze, or the opposite would happen. But neither of these two situations occur, nor is the musician the opposite of the grammarian. The commentator follows pseudo-Alexander in referring to Aristotle's subsequent explanation in E 3 on the matter of the reason why accidental beings do not give rise to generation and destruction. ${ }^{165}$

In the next passage, Aristotle says that we need to describe, as far as possible, the nature of the accidental and from what causes it proceeds. Then it will also become clear why there is no science of it. ${ }^{166}$ Pseudo-Alexander writes that Aristotle will now explain why, although it is among the not-being things, the accident is nonetheless included among the entities. ${ }^{167}$ This claim is found in pseudo-Philoponus's commentary too. ${ }^{168}$ Aristotle now distinguishes between beings that are always in the same state and are of necessity (not necessity in the sense of compulsion, but because they cannot be otherwise) and those that are of necessity nor always, but for the most part. This would be the principle and the cause of the existence of the accident: in fact that which is neither always nor for the most part, we call accident. Aristotle provides several examples. If in the dog-days there is wintry and cold weather, we say this is an accident, but the same cannot be said if it is hot, since this happens always or for the most part. It is also an accident that a man is pale, since this happens neither always nor for the most part, whereas it is no accident that man is an animal. For a builder to produce health is also accidental, because it is the nature not of the builder but of the doctor

\footnotetext{
${ }^{164}$ Cf. pseudo-Alexander, In Metaph., p. 450, 15-27.

${ }^{165}$ Cf. pseudo-Philoponus, In Metaph., p. 24 v.

${ }^{166}$ Cf. Aristotle, Metaph. E 2, 1026 b 24-27.

${ }^{167}$ Cf. pseudo-Alexander, In Metaph., p. 450, 30-32.

${ }^{168}$ Cf. pseudo-Alexander, In Metaph., p. 24 v.
} 
to do this. Then a confectioner may make something wholesome, but not in virtue of the confectioner's art. We can thus say that this happens by accident, and there is a sense in which he makes it, but in the unqualified sense it does not. ${ }^{169}$

The threefold division of the entities mentioned at the beginning of the passage reflects Aristotle's conception of the relationship between science and reality. Science only concerns two kind of entities, i.e. those that are always and of necessity, which are the object of the more and the less exact sciences (such as mathematics and physics, respectively). No science exists, on the other hand, for entities that are neither always nor for the most part. Asclepius identifies the entities that are of necessity with the divine entities ( $\tau \dot{\alpha} \theta \varepsilon i \tilde{\alpha})$ (since the God is good of necessity, not in the sense of compulsion, but because of the divine substance), and with man, as an animal. An example of entities that are, not of necessity but for the most part, is a man who has five fingers. ${ }^{170}$ Pseudo-Alexander also uses man as an example of entities that are always and of necessity, since he is always and of necessity an animal. Since 'necessary' can also be used to indicate a compulsion, the commentator feels the need to specify that Aristotle would say that 'necessity' must not be understood here in the sense of 'compulsion': man is an animal always and of necessity, not because he is obliged to be an animal, but inasmuch as he is unable to not be an animal. As an example of accidental being, pseudo-Alexander mentions man who, for the most part, has five fingers ${ }^{171}$, which had already appeared in Asclepius's commentary. The subsequent definition of accident as an «interval $\left(\delta \dot{\alpha}^{\prime} \lambda \varepsilon 1 \mu \mu \alpha\right)$ of 'for the most part' ${ }^{172}$ suggests that an accident is something that interrupts the occurrence of what happens always or for the most part. ${ }^{173}$

Aristotle goes on to say that, while to other things answer faculties productive of them, to accidents there corresponds no determinate art nor faculty, for the causes of things that are or come to be by accident are also accidental. ${ }^{174}$ Asclepius, pseudo-Alexander and pseudoPhiloponus all explain that Aristotle claims that things that are per se, and that happen for the

${ }^{169}$ Cf. Aristotle, Metaph. E 2, 1026 b 27-1027 a 5.

${ }^{170}$ Cf. Asclepius, In Metaph., p. 368, 11-18.

${ }^{171}$ Cf. pseudo-Alexander, In Metaph., pp. 451, 4-14 and p. 451, 15, where accident is described as «what interrupts the continuity of the 'for most part'».

${ }^{172}$ Cf. pseudo-Alexander, In Metaph., p. 451, 13-14.

${ }^{173}$ Cf. Cauli, in Movia, Commentario alla "Metafisica", p. 1186 note 152.

${ }^{174}$ Cf. Aristotle, Metaph. E 2, 1027 a 5-8. According to many scholars the text is corrupt: see Ross, Metaph., vol. I, 360-361. 
most part are produced by the arts - as medicine produces health, for example - while for things that are accidentally there is no art or determinate power. ${ }^{175}$

In the next passage Aristotle poses as principle of accidental being the fact that not all things are or come to be of necessity and always. For instance, for a pale man to be a musician does not happen always nor even for the most part, and - since it happens only occasionally - it must be accidental. If this were not the case then everything would be of necessity. ${ }^{176}$ Here Aristotle returns to the classification of entities introduced a little earlier on ${ }^{177}$, and he says that most of these entities belong to things that are or that come into being for the most part. They are natural entities or occurrences that are governed by laws, and that consequently take place regularly. The existence of the accident is made necessary by the presence of other beings that do not belong to this class, but are rather classifiable among the contingent realities. On this issue, pseudo-Alexander refers to the second section of $D e$ interpretatione, where "it is demonstrated that not all things are of necessity, but that there is also the contingent". ${ }^{178}$ The commentator probably means to refer to De interpret. 9, where, as we know, Aristotle deals with contingent futures. Asclepius and pseudo-Philoponus restrict themselves to following Aristotle's text. ${ }^{179}$

As a consequence of the above-mentioned claim, Aristotle posits that matter must be the cause of the accident, since it is capable of being otherwise than as it usually is. ${ }^{180}$ On this passage, Asclepius comments that cause of the accident must be the matter because it can receive something different from the way it is for the most part, and he uses Aristotle's example of it being cold weather in dog-day. ${ }^{181}$ Pseudo-Alexander explains that matter possesses a nature such that it may be that men are sometimes born with five fingers, and sometimes with four or six. ${ }^{182}$ Pseudo-Philoponus goes along with pseudo-Alexander's comment. ${ }^{183}$ Aristotle then says that we need to consider the question of whether there can be

${ }^{175}$ Cf. Asclepius, In Metaph., p. 368, 32-38; pseudo-Alexander, In Metaph., p. 451, 33-38; pseudoPhiloponus, In Metaph., p. 24 v.

${ }^{176}$ Cf. Aristotle, Metaph. E 2, 1027 a 8-13.

${ }^{177}$ Cf. Aristotle, Metaph. E 2, 1026 b 28-31.

${ }^{178}$ Pseudo-Alexander, In Metaph., p. 452, 8-10.

${ }^{179}$ Cf. Asclepius, In Metaph., p. 369, 4-9; pseudo-Philoponus, In Metaph., pp. 24 v-25 r.

${ }^{180} \mathrm{Cf}$. Aristotle, Metaph. E 2, 1027 a 13-15.

${ }^{181}$ Cf. Asclepius, In Metaph., p. 369, 10-12; Aristotle, Metaph. E 2, 1026 a 33.

${ }^{182}$ Cf. pseudo-Alexander, In Metaph., p. 452, 10-16.

${ }^{183}$ Cf. pseudo-Philoponus, In Metaph., p. 25 r. 
anything that is neither always nor for the most part as our starting-point. For there to be only what is of necessity or for the most part is impossible, so - besides these - there is what happens in some way or other and by accident. For the solution to the question that follows immediately, i.e. whether there is only the for the most part, or whether there are also eternal beings, the reader is referred elsewhere. ${ }^{184}$

The definition of accident as what happens by chance recalls what Aristotle says in Phys. II 5, 196 b 10-17, where chance is defined in the same way as accident. ${ }^{185}$ The reference to the solution of the problem of whether eternal beings exist or not concerns the demonstration of the existence of unmoved movers, and therefore Metaph. $\Lambda$. To explain this passage, Asclepius says that it is impossible for nothing to exist that is neither always nor for the most part because the evidence suggests that the God is always good, and that the doctor heals for the most part. So, if what is for the most part exists, then accidental being exists in entities too. The commentator believes that the reference in the conclusion of Aristotle's passage is to the Physics ${ }^{186}$, where Aristotle would demonstrate the existence of eternal matter. ${ }^{187}$ Pseudo-Alexander identifies the $\dot{\alpha} \rho \chi \eta$ on 1.15 with the «way or rule» to be followed in order to demonstrate that accident exists. ${ }^{188}$ The commentator explains that:

if somebody wishes to demonstrate that accident exists, he must assume as principle that there is something beyond what is always and what is for the most part. If he assume this starting-point, whenever he asks his interlocutor whether or not something exists beyond what is always and what is for the most part, and the latter, persuaded by the evidence, grants that there is certainly something beyond what has been said, this is what can be in some way or other, that is the accident. ${ }^{189}$

Going beyond Aristotle's text, pseudo-Alexander clarifies at the beginning of his argumentation that those who intend to demonstrate the existence of accidental must first assume as principle that something exists that is not classifiable as being always or for the most part. This assumption will enable him to proceed with the demonstration, and will lead the interlocutor to admit of the existence of accident on evidence-based grounds. According

${ }^{184}$ Cf. Aristotle, Metaph. E 2, 1027 a 15-19.

${ }^{185}$ Cf. Berti, Métaphysique, p. 158.

${ }^{186}$ Cf. Aristotle, Phys. I 9.

${ }^{187}$ Cf. Asclepius, In Metaph., p. 370, 14-22.

${ }^{188}$ Cf. pseudo-Alexander, In Metaph., p. 452, 15-16.

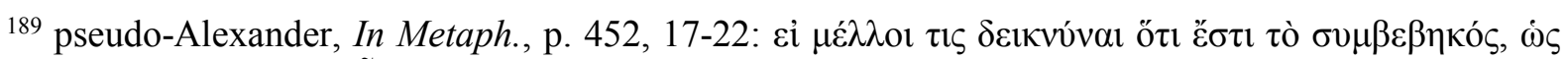

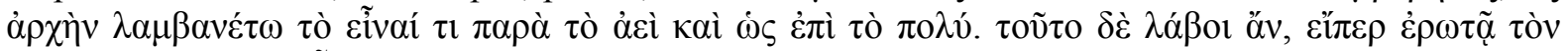

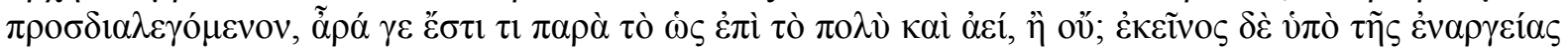

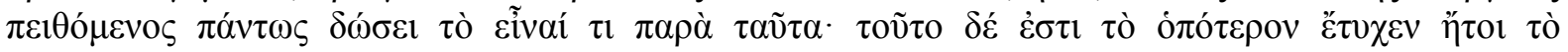
$\sigma u \mu \beta \varepsilon \beta \eta \kappa o ́ s$. 
to pseudo-Alexander, when Aristotle refers the reader elsewhere for the solution of the problem of whether eternal entities exist or not, he means Books $\mathrm{K}$ and $\Lambda$ of the Metaphysics, in which Aristotle speaks about the problem of eternal entities, in a rather obscure manner in the former book, and more thoroughly in the latter. ${ }^{190}$ Pseudo-Philoponus once again follows pseudo-Alexander, and reiterates this last part of the latter's comment almost word for word. ${ }^{191}$

In the final part of the chapter, Aristotle says it is obvious that there is no science of the accident because all science is either what is always or what is for the most part. Otherwise it would be impossible to learn, or to teach another. It must be possible to establish what is the object of science as what is always or for the most part. For instance, honey-water is - for the most part - useful to a patient in a fever. But it will be impossible to say when this is not the case - on the day of new moon, for instance - because what happens on the day of new moon also happens either always or for the most part, while accident is outside the always and for the most part. ${ }^{192}$ On line 1027 a 25 , in manuscript $\mathrm{E}$ we find $\pi$ ó $\varepsilon \varepsilon$ ov้, while ov้ is omitted in

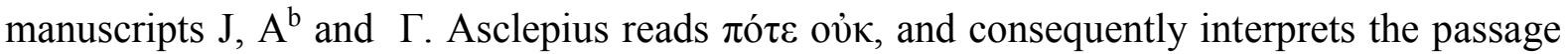
in the sense that the benefit of honey-water for the person with a fever does not occur, and this prompts the occurrence of what happens neither always nor for the most part; so it happens by accident, which cannot be the object of science. ${ }^{193}$ Pseudo-Alexander, followed by pseudo-Philoponus, claims instead that nobody will be capable of teaching (or learning) what goes beyond what happens for the most part - what is useful when there is a new moon, for instance - because this happens rarely. In fact, it is not that people who drink honey-water when there is a new moon will benefit for the most part, but rather that it is for the most part useful to those who drink it that it happens to be beneficial when there is a new moon. Vice versa, the commentator concludes, what is beneficial when there is a new moon is beneficial either always or for the most part. But, because accident goes beyond these situations, there

${ }^{190}$ Cf. pseudo-Alexander, In Metaph., p. 452, 23-27.

${ }^{191}$ Cf. pseudo-Philoponus, In Metaph., p. 25 r: Hoc cum dixit interrogat, utrum id quod ut plurimum est in entibus, semper vero et necessario non est, vel ut aeterna, et quae ut plurimum? et respondet quod postea considerabit de ipsis in 11. perfecte vero in 12 = pseudo-Alexander, In Metaph., p. 452,

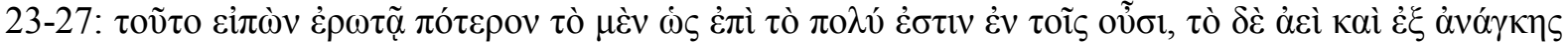

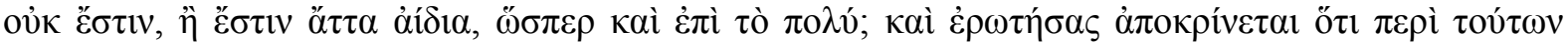

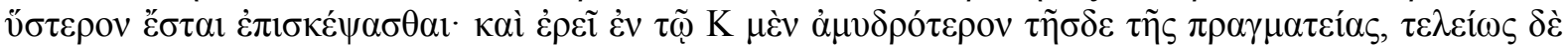
$\dot{\varepsilon} \vee \tau \tilde{\omega} \Lambda$.

${ }^{192}$ Cf. Aristotle, Metaph. E 2, 1027 a 19-26.

${ }^{193}$ Cf. Asclepius, In Metaph., p. 370, 28-30. 
can be no science dealing with it. ${ }^{194}$ The sense of Aristotle's discourse seems to be that accident is distinguishable from what happens always or for the most part (and can be the object of science) by the fact, for instance, that honey-water can be beneficial for a person with a fever. It is impossible to establish when this might not be the case, such as when there is a new moon, because the new moon can also be classified as something that occurs either always or for the most part, whereas accident cannot.

Thus far, we have tried to demonstrate that, according to our commentators, all of Aristotle's discourse about accident focusing on demonstrating that there can be no science dealing with it would aim specifically to exclude accident from the object of theological science, rather than from the object of the other sciences. By virtue of this, the second and subsequent chapters in Book E would be fully consistent with the line of reasoning Aristotle develops in the Metaphysics. The conclusive passage in chapter 2, which brings up the problem of the cause of accident, must continue in the same direction. In their comments on Aristotle's final claim to have demonstrated what accident is, what causes it, and that there is no science dealing with it ${ }^{195}$, both Asclepius ${ }^{196}$ and pseudo-Alexander identify matter as the cause of accident, based on 1027 a 13-15. The problem of what kind of cause the accident has is discussed in chapter 3 , where the question is open to new possible solutions.

\section{Accident and its cause}

The theory that Aristotle intends to demonstrate in E 3 is stated in the incipit: it is obvious that there are principles and causes which are generable and destructible without ever being in course of being generated or destroyed. The demonstration that follows is a sort of reductio ad absurdum: if this were not so, everything would happen necessarily, since what is generated or destroyed must have a cause that is not accidental, that is per se. ${ }^{197}$

To explain Aristotle's passage, Asclepius says that accidental causes are generated and destroyed qua entities ( $\dot{\omega} \varsigma$ óv $\tau \alpha$ ), not because they are generated things, since these causes are not determinate and in a strict sense. On this topic, the commentator gives the example of the horse being used in a war that ran away because it was thirsty and, in doing so, it saved its

\footnotetext{
${ }^{194}$ Cf. pseudo-Alexander, In Metaph., pp. 452, 34-453, 2.

${ }^{195}$ Cf. Aristotle, Metaph. E 2, 1027 a 26-28.

${ }^{196}$ Cf. Asclepius, In Metaph., p. 371, 3-4; pseudo-Alexander, In Metaph., p. 453, 5-6.

${ }^{197}$ Cf. Aristotle, Metaph. E 3, 1027 a 29-32.
} 
skin: Asclepius explains that the horse did not run away to stay safe, but because it was thirsty. ${ }^{198}$ What Asclepius seems to be saying is that the causes of accidental being are not generated and do not perish in the same way as causes per se, the generation and destruction of which are part of a process the purpose of which is their generation and destruction. Instead, they come into being and are destroyed fortuitously, so they exist and cease to exist inasmuch as they are entities, not inasmuch as they are the result of a process having as its object their generation or destruction. Pseudo-Alexander explains that accidental causes are and are not without any generation or destruction, like contacts ( $\alpha i \dot{\alpha} \varphi \alpha i)$, and instants ( $\tau \dot{\alpha}$ vvv). ${ }^{199}$ He says Aristotle assumes that it is commonly accepted that entities with causes and principles that exist as a result of a process of generation are of necessity. So, if entities with causes that come into being through generation (such as a house) come to be of necessity, then the causes of entities that are not of necessity are and are not without any generation or destruction. If this were not so, i.e. if all causes of entities were necessary and per se, then everything would be necessarily determinate. ${ }^{200}$

Aristotle clarifies the above considerations by posing the question of whether 'this something' ( $\tau \circ \delta i$ ) will occur or not. The answer is that it will occur if another thing happens, while it would not occur if the latter were not to happen. This affirmations are followed by examples of future events. Aristotle says that, if we always subtract time from a limited extent of time, we will obviously come to the present: so a given man will die of disease or by violence if he leaves his home, and this will happen if he gets thirsty. But this will only happen if another event occurs, and in this way we will arrive at the present, or at what has already happened. For instance, the man will leave his home if he gets thirsty, and he will get thirsty if he is eating salty food. But this will or will not happen, so the man will or will not die. ${ }^{201}$ As an example of the event that might happen, Asclepius returns to the sea-battle that

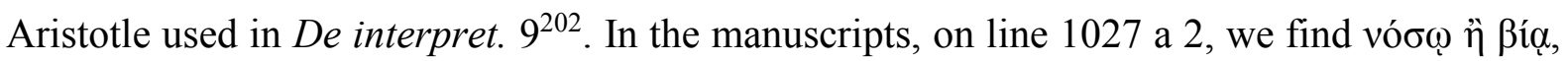

\section{${ }^{198}$ Cf. Asclepius, In Metaph., p. 371, 8-17. Cf. Aristotle, Phys. II 6, 197 b 15-18.}

${ }^{199}$ Pseudo-Alexander gives the example of the builder who is per se the cause of the house, who also happens to be the cause of the fact that the house produces shade, or that somebody finds it unpleasant. The builder has become the cause of this not through generation or learning, but through these processes he has become a builder (cf. pseudo-Alexander, In Metaph., pp. 453, 11-454, 1). We find the same example in pseudo-Philoponus's commentary (cf. pseudo-Philoponus, In Metaph., p. 25 r).

\footnotetext{
${ }^{200}$ Cf. pseudo-Alexander, In Metaph., p. 454, 7-33.

${ }^{201}$ Cf. Aristotle, Metaph. E 3, 1027 a 32-b 6.

${ }^{202}$ Cf. Asclepius, In Metaph., pp. 372, 35-373, 3.
} 
but Ross expunges vóọ ì because he believes that it derives from line a 10, where the same expression appears. Asclepius keeps to the version of the manuscripts and explains that the man will die of disease if the harmony between the opposing elements comprising his body is disrupted; or he will die by violence if he is assaulted by his enemies because he has left town having eaten salty food. ${ }^{203}$ Pseudo-Alexander dedicates a lengthy exegesis to Aristotle's passage. He gives the man the name of Nicostratus and claims that he will die if he has left town and been captured by his enemies during a siege. The commentator explains that the cause of his death will be having left town, which is caused by his wishing to drink some water; this in turn will have been caused by his getting thirsty, and his thirst has been caused by his having eaten salty food. Pseudo-Alexander identifies this last cause as accidental and not per se, since it is possible to get thirsty without having eaten salty food - after strenuous physical exertion, for instance. ${ }^{204}$ So it seems that, in the commentator's view, the cause of Nicostratus's death - having eaten salty food - is accidental inasmuch as his death could have been caused by a plurality of fortuitous events. The same explanation of Aristotle's passage can be found in pseudo-Philoponus's commentary. ${ }^{205}$

Pseudo-Alexander considers the possibility of the man dying due to disease in his comment on 1027 a 10-11, where the expression vóọ ì ßía comes up again. He explains that the living being is such because opposites (fire and earth) and intermediates have been generated therein; and because of the battle that takes place between the opposing elements, a man may become ill, and if he has drunk too much water he will become ill with dropsy. Drinking too much water will therefore be the cause of his dropsy, and dropsy will be the cause of his death, but it will not be a cause per se because people can become ill with dropsy even if they have not drunk any water. ${ }^{206}$ So it would seem that, in pseudo-Alexander's view, an accidental cause would be a cause that slips into a series of causes per se, and triggers the occurrence of an event that does not maintain the necessary bond with its cause because it could also have been triggered by another, different cause. Asclepius seems to retain the necessary bond between the effect and its cause, however. He acknowledges that the cause behind the survival of the horse that escaped death in war was its thirst, the effect of which was to induce the animal to go looking for water. Aristotle seems to admit of this possibility:

\footnotetext{
${ }^{203}$ Cf. Asclepius, In Metaph., p. 373, 5-20.

${ }^{204}$ Cf. pseudo-Alexander, In Metaph., pp. 454, 34-455, 2.

${ }^{205}$ Cf. pseudo-Philoponus, In Metaph., p. 25 r.

${ }^{206}$ Cf. pseudo-Alexander, In Metaph., pp. 455, 38-456, 15.
} 
the series of causes he describes is a succession of accidental causes, which become per se to the degree in which they give rise to a certain event.

After explaining the case of future events, Aristotle applies the same approach to past events as well. What has happened, he argues, can already be found in something, i.e. in a thing of the past, so all future things will then be of necessity, as when the living die, for instance, because something has happened, like the presence of opposing elements in the same body. What remains indeterminate, however, is whether the living will die of disease or by violence, and this depends on the occurrence of a certain situation. ${ }^{207}$ We find the term $\sigma \omega ́ \mu \alpha \tau \imath$ after $\alpha \hat{\tau} \tilde{\varphi}$ in $\mathrm{b} 10$ in the manuscripts $\mathrm{E}$ and $\mathrm{J}$, but not in $\mathrm{A}^{\mathrm{b}}$ or in pseudoAlexander. ${ }^{208}$ Neither of the two cases poses problems in the interpretation of the passage. Aristotle claims here that even accidental past events can be brought down to a previous accidental cause, which becomes the cause per se of the event that it triggers, since the event necessarily depends on it. The presence of opposing elements in the individual is thus the cause per se of his death, but whether he died of disease or by violence remains indeterminate because this will depend on the occurrence of a certain situation. As we have seen, the passage was discussed by Asclepius in his comment on 1027 b $2^{209}$, when the expression

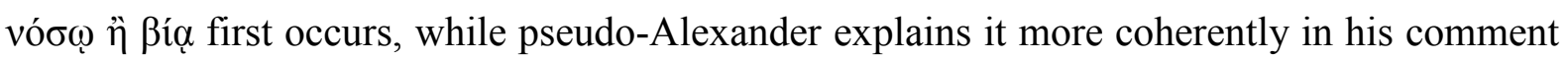
on this section of Aristotle's text. Pseudo-Philoponus keeps close to Aristotle's words. ${ }^{210}$

Aristotle goes on to say it is evident that we can go back to a certain starting-point that it will be impossible to bring down to another: this will be the starting-point of what happens by chance, and there will be no other cause of its coming to be. ${ }^{211}$ The accidental cause is therefore presented here as a principle that, as such, cannot be brought down to any other cause. The term $\alpha \lambda \lambda o$ in 1027 b 13 is omitted from the manuscripts E, J, $\Gamma$, and also in Asclepius $^{212}$, because there is really no cause of the principle, but the term appears in $\mathrm{A}^{\mathrm{b}}$, and in pseudo-Alexander. ${ }^{213}$ Asclepius identifies the principle in question with eating salty food, and thus with the accidental cause of a violent death. He specifies that this principle can also happen in another way, and there is no determinate cause of its coming to be, since this is

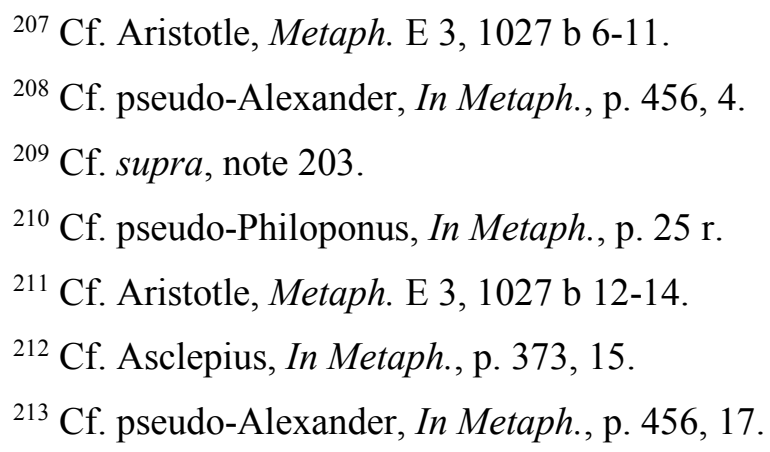


impossible. Asclepius also mentions the battle of the elements that have produced the disease as an accidental cause, showing that - alongside accidental causes consisting of human decisions - he also considers accidental causes consisting of natural facts. ${ }^{214}$ PseudoAlexander (followed by pseudo-Philoponus ${ }^{215}$ ) identifies the accidental cause with having eaten salty food, and he describes it as the principle of what can happen in different ways, i.e. of the fact that the individual has died. ${ }^{216}$ Among the modern interpreters, Sorabji mentions the name of Nicostratus in his comment on Aristotle's passage, and he suggests that the accidental cause of the Nicostratus's death, i.e. the encounter with his enemies, does not in turn have any cause. This would happen as a result of the combination of two series of independent causes, i.e. Nicostratus's departure from the town and the presence of the enemy, and so it would be the fact that these two events occurred simultaneously that would remain without cause. ${ }^{217}$ Aristotle could be referring, however, to a single accidental cause (having eaten salty food), which slips into the chain of causes per se and produces an accidental event.

The chapter ends with Aristotle saying that the question of what sort of starting-point and what sort of cause we refer the accidental causes - whether to matter of to the purpose or to the motive power - needs to be carefully examined. ${ }^{218}$ This might mean that we need to see to what genus of cause we must refer the accidental cause by considering every case in its particular aspects. In addition to the possible types of causes suggested by Aristotle, Asclepius also suggests the formal cause as he believes (like pseudo-Alexander ${ }^{219}$ and pseudo-Philoponus ${ }^{220}$ ) that the accidental cause should be refer to the efficient cause. ${ }^{221}$ Sorabji wonders how the determinism that he attributes to Aristotle, and that would emerge in Metaph. E 3, can be reconciled with what Aristotle would claim in the Ethics. ${ }^{222}$ In actual

\footnotetext{
${ }^{214}$ Cf. Asclepius, In Metaph., p. 373, 13-20.

${ }^{215}$ Cf. pseudo-Philoponus, In Metaph., p. 25 r.

${ }^{216}$ Cf. pseudo-Alexander, In Metaph., p. 456, 16-22.

${ }^{217}$ Cf. Richard Sorabji, Necessity, Cause, and Blame: Perspectives on Aristotle's Theory (London, Durckwort 1980), pp. 10-13.

${ }^{218}$ Cf. Aristotle, Metaph. E 3, 1027 b 14-16.

${ }^{219}$ Cf. pseudo-Alexander, In Metaph., p. 456, 22-25.

${ }^{220}$ Cf. pseudo-Philoponus, In Metaph., p. 25 r.

${ }^{221}$ Cf. Asclepius, In Metaph., p. 373, 22-26.

${ }^{222}$ Sorabji, Necessity, Cause, and Blame, pp. 251-256. The theory has been criticised by many interpreters, including Gail Fine, Aristotle on Determinism: A Review of Richard Sorabji's Necessity, Cause and Blame, «The Philosophical Review», 90 (1981), pp. 561-579.
} 
fact, from Metaph. E 3 there is nothing to suggest that Aristotle had taken a deterministic stance: admitting the existence of accidental causes leaves room for freedom and for human choice. $^{223}$

\section{Being as truth and not-being as falsity}

After dealing with accidental being, Aristotle says we now need to concern ourselves with being as truth and not-being as falsity, which respectively depend on combination and separation. The set of both together depends on the allocation of a pair of contradictory judgements: in fact, truth is the affirmation of what is really combined, and the negation of what is really separated, whereas falsity has the opposite of this allocation. ${ }^{224}$

Being as truth and not-being as falsity had been mentioned as a second meaning of being in the incipit of Metaph. E 2, and as a third meaning of being in Metaph. $\Delta 7$. Here, Aristotle explains that 'being' and 'is' mean that a statement is true; e.g. "Socrates is musical» means that this is true. He says that 'not-being' mean that a statement is not true but false, as when we say that «the diagonal of the square is not commensurate with the side», since this is false. ${ }^{225}$ The term $\dot{\varepsilon} \pi \varepsilon 1 \delta \eta$ on line 1027 b 19 introduces the protasis of a proposition with no apodosis, as already happened in the incipit of chapter 2. Bonitz and Jaeger make the apodosis begin on line 1027 b 28, while Ross would have it begin on line $b$ 33. Asclepius explains Aristotle's passage by saying that not-being qua falsity denotes nonexistent things, like the hircocervus, since things that do not exist are said to be false. That true and false have to do with combination and separation, and that they concern the allocation of a pair of contradictory judgements means, according to Asclepius, that an affirmation is true when we place together things having the same nature, which is contrary to the false affirmation; the situation is much the same for negation. ${ }^{226}$ In 1027 b 19 Asclepius reads $\pi \varepsilon \rho i ́$, while in pseudo-Alexander and manuscripts E, J, $\mathrm{A}^{\mathrm{b}}$ and $\Gamma$ we find $\pi \alpha \rho \alpha ́$. PseudoAlexander explains Aristotle's passage by saying that 'being' and 'not-being' concern

${ }^{223}$ I supported this idea in Rita Salis, The Accident and its Causes: Pseudo-Alexander on Aristotle (Metaphysics E 3), in Konstantinos Boudouris (ed.), Proceedings of the XXIII World Congress of Philosophy (Athens, 4-10 August 2013), (Charlottesville, Virginia 2018, Philosophy Documentation Center, vol. 2, section II), pp. 297-302.

\footnotetext{
${ }^{224}$ Cf. Aristotle, Metaph. E 4, 1027 b 17-23.

${ }^{225} \mathrm{Cf}$. Aristotle, Metaph. $\Delta$ 7, 1017 a 31-35.

${ }^{226}$ Cf. Asclepius, In Metaph., pp. 373, 28-374, 1.
} 
combination and separation inasmuch as truth is said 'being', and falsity is said 'not-being'. The commentator gives the example of the phrase «Socrates is seated», and explains that this is said to be true when the property of being seated belongs to Socrates and we associate it with him. If instead, when Socrates is seated, we say that he is not seated, since this is false, it is said 'not-being' inasmuch as it has been erroneously divided. The commentator goes on to say that falsity introduces the allocation of a pair of contradictory judgements, i.e. it constitutes the other part of the contradiction: while being as truth occurs when the predicate is connected with truth with the subject, not-being as falsity is the opposite. ${ }^{227}$ This last part of pseudo-Alexander's comment is echoed in the words of pseudo-Philoponus. ${ }^{228}$

Then Aristotle declares that the question of the way in which it happens that we think simultaneously $(\alpha \ddot{\mu} \alpha)$ or separately ( $\chi \omega \rho i ́ s)$ so that, instead of a succession, something

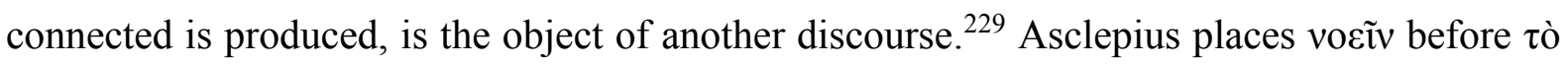
$\alpha \check{\mu} \alpha$ on line 1027 b 33, and says that this thought does not consist of a series of objects, such as man, horse, dog, inasmuch as each of these is neither true nor false. Instead, we need to say «man is an animal» if we are dealing with an affirmation, or «man is not an animal» if we are dealing with a negation ${ }^{230}$. Pseudo-Alexander, followed by pseudo-Philoponus ${ }^{231}$, refers to Metaph. $\mathrm{Z}$ as the place where Aristotle is concerned with this issue, and he give an example of things that can be thought together although they are said separately, such as «animal, terrestrial and biped». As an example of the thought of things that form a succession, and that must be excluded, the commentator mentions the Iliad, which consists of a series of books. ${ }^{232}$

Aristotle says that, as a consequence of the above considerations, truth and falsity are not in things, as if good were true and bad were in itself false, but rather in thought ( $\dot{\varepsilon} v$ $\delta 1 \alpha v o i$ ). Truth and falsity therefore should not be confused with the combination and separation of things, since - were that to happen - good would immediately be true and bad would immediately be false. As for simple concepts and essences, falsity and truth do not exist even in thought - but for the discussion on that which is or is not in this sense the reader

\footnotetext{
${ }^{227}$ Cf. pseudo-Alexander, In Metaph., pp. 456, 30-457, 10.

${ }^{228}$ Cf. pseudo-Philoponus, In Metaph., p. 25 r.

${ }^{229}$ Cf. Aristotle, Metaph. E 4, 1027 b 23-25.

${ }^{230}$ Cf. Asclepius, In Metaph., p. 374, 1-4.

${ }^{231}$ Cf. pseudo-Philoponus, In Metaph., p. 25 r.

${ }^{232}$ Cf. pseudo-Alexander, In Metaph., p. 457, 10-19.
} 
is referred elsewhere. ${ }^{233}$ Asclepius interprets the claim that truth and falsity are not in things as meaning that they are in discourses ( $\dot{\varepsilon} v \tau$ oĩ $\varsigma$ $\lambda$ ó $01 \varsigma$ ), i.e. in propositions, and as an example he uses the phrase «true is good, while false is bad». ${ }^{234}$ The terms are reversed here, as Aristotle says that «good is true» and that «bad is false» to rule out the theory in opposition to his own. ${ }^{235}$ Pseudo-Alexander comments on the passage by saying that being as truth and notbeing as falsity concern the combination and separation, since falsity and truth are not found in things. In fact, if truth and falsity were not an affection of our thought, and did not concern combination and separation, but were in things, then by saying 'good' we would also be saying 'true', and good would be true, just as by saying 'bad' we would be saying 'false'. The commentator explains that simple things are «intelligible entities per se, without combination and separation». ${ }^{236}$ Pseudo-Alexander must therefore read the term $\varepsilon \dot{v} \theta \dot{v} \varsigma$, which is not in the manuscripts $\mathrm{E}$ and $\mathrm{J}$, but appears in the manuscript $\mathrm{A}^{\mathrm{b}} \cdot{ }^{237}$ The commentator thus interprets Aristotle's passage in the sense that truth and falsity are not in things, since - if they were good would refer directly to truth and bad to falsity, a theory that Aristotle rules out.

This last time the reader is referred elsewhere, it is to Metaph. $\Theta 10$, if we accept that the reference to the sense of being is to being as truth and not-being as falsity, as pseudoAlexander suggests ${ }^{238}$. This raises the problem of how to reconcile the reference with what Aristotle says in b 33-34, i.e. that we need to leave aside accidental being and being as truth. Asclepius avoids the contradiction by replacing the expression in 1027 b 29: «that which is in

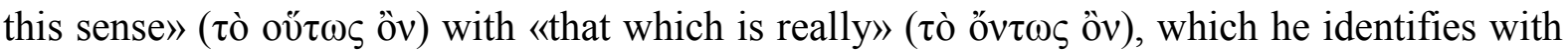
being per se. ${ }^{239}$ This interpretation would mean that the reference is to the figures of predication, which is discussed in Metaph. $\mathrm{Z}$ and $\mathrm{H}$. It has been suggested that this might be an erroneous reference in the manuscript used by Asclepius. ${ }^{240} \mathrm{Be}$ that as it may, the

${ }^{233}$ Cf. Aristotle, Metaph. E 4, 1027 b 25-29. Jaeger believed that lines 1027 b 25-29 were a later addition of the same period as Metaph. $\Theta$ (cf. Werner Jaeger, Studien zur Entstehungsgeschichte der Metaphysik des Aristoteles (Berlin, Weidmann 1912), pp. 21-28; Werner Jaeger, Aristoteles. Grundlegung einer Geschichte seiner Entwicklung (Berlin, Weidmann 1923), p. 212; Werner Jaeger, Aristotelis Metaphysica, recognovit brevique adnotatione critiqua instruxit Werner Jaeger (Oxford, Clarendon Press 1992), in app. cr.).

\footnotetext{
${ }^{234}$ Cf. Asclepius, In Metaph., p. 374, 5-6.

${ }^{235}$ Cf. Aristotle, Metaph. E 4, 1027 b 26-27.

${ }^{236}$ Cf. pseudo-Alexander, In Metaph., p. 457, 20-36.

${ }^{237}$ So also pseudo-Philoponus, In Metaph., p. 25 r.

${ }^{238}$ Cf. pseudo-Alexander, In Metaph., pp. 457, 39-458, 1.

${ }^{239}$ Cf. Asclepius, In Metaph., p. 374, 9.

${ }^{240}$ Cf. Berti, Métaphysique, p. 194.
} 
reference contained in Asclepius certainly responds better to the problem of how to place Book E in Aristotle's Metaphysics, given that it acknowledges a connection with the books that follow in relation to the core topic of the work: first philosophy.

In the final part of Book E, Aristotle says that since the combination and the separation are in thought and not in things, and «that which is in this sense» is a different sort of 'being' from the things that are in the full sense (in fact, thought unites or separates either the subject's essence, or its having a quality or quantity or something else), accidental being and being as true must be dismissed. ${ }^{241}$ Aristotle seems to return on line $1027 \mathrm{~b} 29$ to the discourse begun on line $\mathrm{b} 19$, and to provide the solution. After reminding us that combination and separation, i.e. affirmation and negation, are in thought, where they give rise to truth and falsity - and therefore being as truth is also in thought - Aristotle concludes that being as truth («that which is in this sense») differs from «from the things that are in the full sense». The latter expression must refer to being according to the different the figures of predication, and to being potentially and actually, i.e. the two principal meanings of being.

To explain this passage Asclepius says that thought unites or separates, uniting the substance with the quantity, the quality, and the other categories, as when we say, for instance, that Achilles is five cubits tall (quantity), or that he is white (quality), or that he is a father (relationship). ${ }^{242}$ Pseudo-Alexander identifies the principal senses of being with individual substances, i.e. with the intelligible that Aristotle discusses in the next book (probably thinking of forms, which are the object of Metaph. Z). The commentator replaces

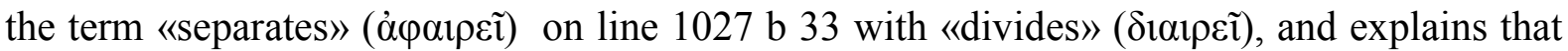

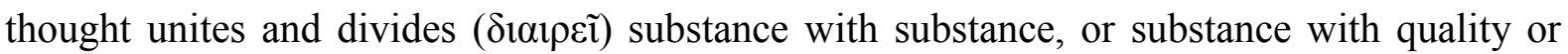
quantity. ${ }^{243}$ Pseudo-Philoponus's comment on this point is rather important because he refers to the interpretation of pseudo-Alexander, attributing it to «the man from Ephesus» ${ }^{244}$ - an important clue supporting the theory that identifies pseudo-Alexander with Michael of Ephesus. $^{245}$

Aristotle's conclusion that accidental being and being as truth must be dismissed implies that they do not have to be part of the science of being qua being. This is because the

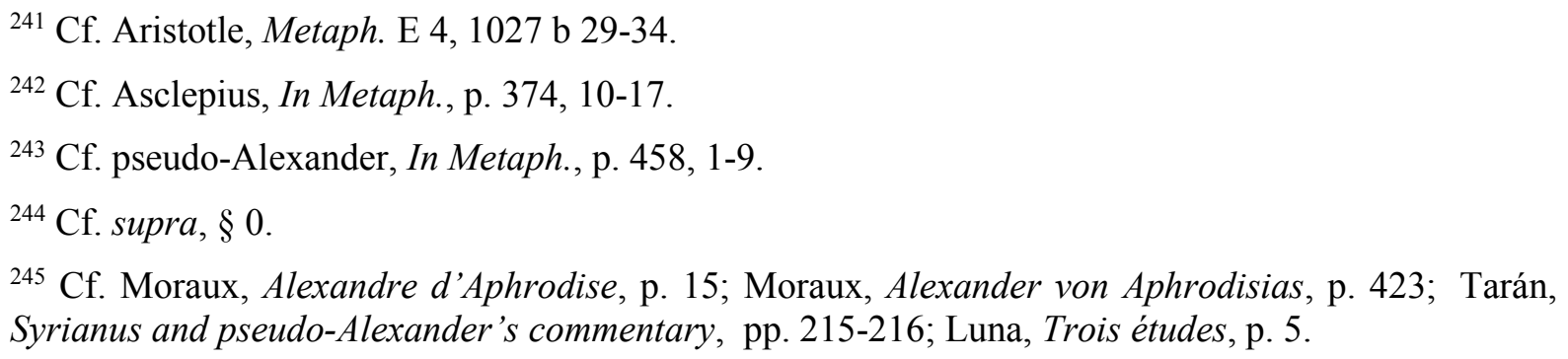
Syrianus and pseudo-Alexander's commentary, pp. 215-216; Luna, Trois études, p. 5. 
cause of the former is indeterminate, and that of the latter is an affection of the thought; both are related on the remaining genus of being, and they do not manifest any separate class of being. ${ }^{246}$ To our commentators, this statement must have sounded like further confirmation of the role of Book E in the whole picture of the Metaphysics: here, Aristotle's aim would be to demonstrate which meanings of being should be the object of first philosophy, and which meanings should remain outside its field of investigation. It is therefore the Aristotelian text itself that gives the commentators the starting-point for their particular interpretation of the whole of Aristotle's work. Asclepius thus believes that the «remaining genus of being» is being per $s e^{247}$, and both pseudo-Alexander and pseudo-Philoponus also think that the remaining genus of being is being intended in the full sense. ${ }^{248}$ The expression «they do not manifest any separate class of being» is interpreted by Asclepius as meaning that accidental being and being as truth revolve ( $\sigma \tau \rho \varepsilon ́ \varphi o v \tau \alpha \iota)$ around $\mathrm{it}^{249}$, while pseudo-Alexander suggests that it means that these meanings of being «do not manifest any class of being that is separate and goes beyond being». ${ }^{250}$ The expression might refer to what was claimed a little earlier, i.e. that since the cause of accidental being is indeterminate, and since being as truth is an affection of the thought, they must be excluded from the investigation. ${ }^{251}$ The nature of these two ways of being would be subordinate and dependent on being per se, i.e. on the remaining meaning of being, and they would not refer to any concrete reality outside the same meaning of being.

Book E concludes with the claim that we need to dismiss these meanings of being and focus instead on the causes and principles of being itself. Then, returning to what he said in Metaph. Z, Aristotle declares that it is evident that 'being' has numerous meanings. ${ }^{252}$

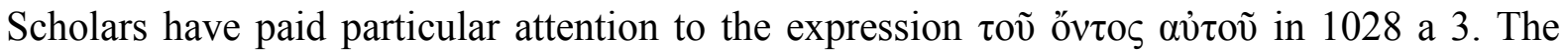
translation as «Being-itself» would seem to make what Aristotle says here contradict what he says in Metaph. B 4, 1001 a 23, 27 and 30, where the same expression is attributed to the Pythagoreans and to Plato, who respectively admitted of the existence of the Being whose essence consisted of Being-itself, and of the One, whose essence was the One-itself. This

${ }^{246}$ Cf. Aristotle, Metaph. E 4, 1027 b 34-1028 a 2.

${ }^{247}$ Cf. Asclepius, In Metaph., p. 374, 19-20.

${ }^{248}$ Cf. pseudo-Alexander, In Metaph., p. 458, 17; pseudo-Philoponus, In Metaph., p. 25 r.

${ }^{249}$ Cf. Asclepius, In Metaph., p. 374, 20-21.

${ }^{250}$ Cf. pseudo-Alexander, In Metaph., p. 458, 18-19.

${ }^{251}$ Cf. Aristotle, Metaph. E 4, 1027 b 33-1028 a 1.

${ }^{252}$ Cf. Aristotle, Metaph. E 4, 1028 a 3-6. 
doctrine was criticized by Aristotle, however, because it would have meant falling into Parmenides's monism, the doctrine according to which everything can be brought down to a single being or, in other words, to Being-itself. The theory of being having its essence in Being-itself was taken up again in ancient and mediaeval Platonism and, on the strength of the passage in the Exodus ${ }^{253}$, where God says to Moses: "I Am Who I Am", the being intended in this case was identified with the Christian God. The translation of the expression

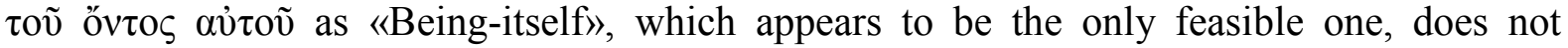
necessarily imply that Aristotle contradicts what he said in Metaph. B. The phrase should therefore be intended not in the technical sense used by Plato and the Platonists, but more simply as referring to being qua being: the adjective $\alpha$ $\tau$ ó $\varsigma$ appears to indicate that the object of the investigation will specifically concern being qua being. The final passage on lines 5-6

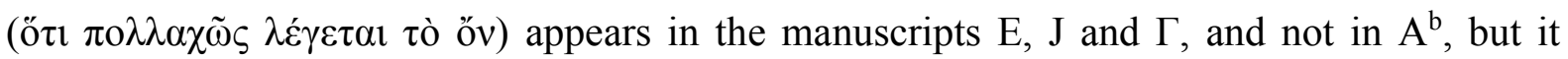
reappears in the opening words of Book Z. After oै $v$, the manuscripts $E, J$ and $\Gamma$ also add:

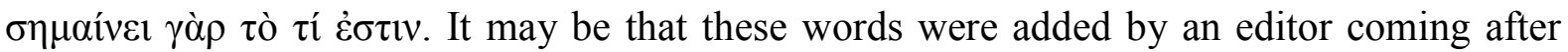
Andronicus to lend unity to the content of the Metaphysics. Book E would thus be better connected to Book $\Delta$, where the different meanings of being are expounded in chapter 7 , and with Book Z, where the closing words of Book E are repeated in the incipit. In commenting on the last part of Book E, Asclepius repeats that we need to examine the causes of being that is in the full sense, i.e. of being per se, since the other causes are investigated therein. ${ }^{254}$ Pseudo-Alexander likewise explains that, since accidental being and being as truth depend on being, and since the investigation focuses on the causes of being qua being, it will also concern these other senses of being, and there will be no need for an investigation dedicated specifically to the latter. ${ }^{255}$ Pseudo-Philoponus and Asclepius ignore the concluding passage, but Hayduck - the author of the critical edition of Asclepius's commentary - believe that it

\footnotetext{
${ }^{253}$ Cf. Ex., 3, 14.

${ }^{254}$ Cf. Asclepius, In Metaph., p. 374, 21-23.

${ }^{255}$ Cf. pseudo-Alexander, In Metaph., p. 458, 17-21.
} 
could be necessary to make an addition to the text. Pseudo-Alexander, on the other hand, makes a reference to the passage, albeit without commenting on it. ${ }^{256}$

The comments on the last section of Book E provide another important element for clarifying the way in which the ancient commentators justified the role of Book E within the framework of the Metaphysics. In the text containing Aristotle's division of the sciences and his awarding of the primacy to theological science, the aim of his treatment of the other meanings of being would have been to emphasize that the investigation conducted in the Metaphysics should properly concern being per se, and to demonstrate that the other meanings of being preserve some sort of link with the principal meaning, i.e. being per se. This served as a further important justification for the unity of the whole of the Metaphysics.

Rita Salis

University of Padua

\section{Bibliography}

Alexandri Aphrodisiensis in Aristotelis Metaphysica commentaria, edidit Hermann Bonitz (Berolini, Reimer 1847).

Alexandri Aphrodisiensis in Aristotelis Metaphysica commentaria (CAG 1), edidit M. Hayduck (Berolini, Reimer 1891).

Alexandri Aphrodisei Commentaria In duodecim Aristotelis libros de prima Philosophia, interprete Ioannes Genesius Sepulveda (Pariis 1536).

Alexandru, Stefan, A New Manuscript of Pseudo-Philoponus' Commentary on Aristotle's 'Metaphysics' Containg a Hitrherto Unknown Ascription of the Work, «Phronesis», 44 (1999), pp. 347-352.

Aristote, La Metaphysique, nouvelle éd. entièrement refondue avec commentaire par Jules Tricot, 2 voll. (Paris, Vrin 1962).

${ }^{256}$ Cf. pseudo-Alexander, In Metaph., p. 458, 23-24. 
Aristoteles, Metaphysik, übersetzt Hermann Bonitz, neu bearbeitet, mit Einleitung und Kommentar hrsg. v. Horst Seidl, griechischer Text in der Edition von Wilhelm Christ, 2 Bde. (Hamburg, Meiner 1978/1980).

Aristotelis Metaphysica, recognovit brevique adnotatione critiqua instruxit Werner Jaeger, (Oxford, Clarendon Press 1992).

Aristotelis Opera, ex recensione Immanuelis Bekkeri, edidit Academia Regia Borussica, 2. ed., accedunt fragmenta, scholia, Index Aristotelicus/addendis instruxit fragmentorum collectionem retractavit O. Gigon, voll. I-II (De Gruyter, Berolini, 1960).

Asclepii in Aristotelis Metaphysicorum libros A-Z commentaria (CAG 6.2), edidit M. Hayduck (Berolini, Reimer 1888).

Berti, Enrico, Aristote. Métaphysique Livre Epsilon, Introduction, traduction et commentaire (Paris, Vrin 2015).

Brandis, Christian August, Scholia in Aristotelem, in Aristotelis Opera, edidit Academia Regia Borussica, vol. IV (Berolini 1836).

Cauli, Norma, Commento al libro E (sesto). Presentazione, traduzione e note, in Giancarlo Movia (ed.), Alessandro di Afrodisia e pseudo-Alessandro, Commentario alla "Metafisica" di Aristotele, (Milano, Bompiani 2007), pp. 1129-1191.

Ebbesen, Sten, Commentators and Commentaires on Aristotle's Sophistici Elenchi: A Study of PostAristotelian Ancient and Medieval Writings on Fallacies, vol. III, Appendix 8 (Leiden, Brill 1981).

Fine, Gail, Aristotle on Determinism: A Review of Richard Sorabji's Necessity, Cause and Blame, «The Philosophical Review», 90 (1981), pp. 561-579.

Freudenthal, Jacob, Die durch Averroes erhaltenen Fragmente Alexanders zur Metaphysik des Aristoteles untersucht und übersetzt, «Abhandlungen der königlichen Akademie der Wissenschaften zu Berlin», phil. hist. Kl., no. 1, Berlin 1884.

Heath, Thomas Little, The Thirteen Books of Euclid's Elements with Introduction and Commentary, vol. I (New York, Dover $1956^{2}$ ).

Jaeger, Werner, Studien zur Entstehungsgeschichte der Metaphysik des Aristoteles (Berlin, Weidmann 1912).

Jaeger, Werner, Aristoteles. Grundlegung einer Geschichte seiner Entwicklung (Berlin, Weidmann 1923).

Kirwan, Christopher, Aristotle, Metaphysics Books Gamma, Delta, and Epsilon, transl. with notes (Oxford, Clarendon Press 1971, 1993² , repr. 1998).

Kremer, Klaus, Der Metaphysikbegriff in den Aristoteles-Kommentaren der Ammonius-Schule (Münster, Aschendorff 1961).

Little Heath, Thomas, The Thirteen Books of Euclid's Elements with Introduction and Commentary, vol. I (New York, Dover $1956^{2}$ ).

Luna, Concetta, Trois études sur la tradition des commentaires anciens à la Métaphysique d'Aristote (Leiden-Boston-Köln, Brill 2001).

Mignucci, Mario, L'argomentazione dimostrativa in Aristotele. Commento agli Analitici secondi, vol. I (Padova, Antenore 1975).

Moraux, Paul, Alexandre d'Aphrodise, exégéte de la Noetique d'Aristote (Liège, Faculté de philosophie et lettres and Paris, Droz 1942).

Moraux, Paul, Aristoteles Werk und Wirkung, Bd. 2: Kommentierung, Überlieferung, Nachleben (Berlin, De Gruyter 1987.) 
Moraux, Paul, Der Aristotelismus bei den Griechen von Andronikos bis Alexander von Aphrodisias, Bd. 3: Alexander von Aphrodisias, herausgegeben Jürgen Wiesner (Berlin-New York, De Gruyter 2001).

Movia, Giancarlo (a cura), Alessandro di Afrodisia e la "Metafisica" di Aristotele (Milano, Vita e Pensiero 2003).

Movia, Giancarlo (ed.), Alessandro di Afrodisia e pseudo-Alessandro, Commentario alla "Metafisica" di Aristotele (Milano, Bompiani 2007).

Patrizi Franciscus, Discussionum Peripateticarum, T. IV, quibus Aristotelica philosophiae universa historiae atque dogmata cum veterum placitis collata eleganter et erudite declarantur (Basel 1581).

Praechter, Karl, recensione a CAG XXII, 2, in «Göttingische gelehrte Anzeigen», 11, 1906, pp. 882899.

Pseudo-Johannis Philoponi Expositiones in Omnes Z Aristotelis Libros Metaphysicos (CAGL 2), Übersetzt Franciscus Patritius, Neudruck der ersten Ausgabe Ferrara 1583 mit einer Einleitung von Charles Lohr (Stuttgart-Bad Cannstatt 1991).

Ptolomeys's Almagest, translated and annotated by Gerald James Toomer, with a foreword by Owen Gingerich (Princeton, Princeton University Press, 1998).

Ravaisson, Félix, Essai sur la Metaphysique d'Aristote, 2 voll. (Hildesheim, Olms 1963).

Reale, Giovanni, Introduzione, traduzione e commentario alla Metafisica di Aristotele, (Milano, Bompiani 2004).

Ross, William David, Aristotle's Metaphysics. A Revised Text with Introduction and Commentary, 2 voll. (Oxford-New York, Oxford University Press for Sandpiper Books 1997).

Salis, Rita, Il commento di pseudo-Alessandro al libro $\Lambda$ della Metafisica di Aristotele, (Soveria Mannelli, Rubbettino 2005).

Salis, Rita, The Accident and its Causes: Pseudo-Alexander on Aristotle (Metaphysics E 3), in Konstantinos Boudouris (ed.), Proceedings of the XXIII World Congress of Philosophy (Athens, 4-10 August 2013) (Charlottesville, Virginia 2018, Philosophy Documentation Center, vol. 2, section II) pp. 297-302.

Schwegler, Albert, Die Metaphysik des Aristoteles, Grundtext, Übersetzung und Commentar, nebst Erläuternden Abhandlungen, 4 Bde. (Frankfurt am Main, Minerva 1960).

Sharples, Robert William, Pseudo-Alexander on Aristotle, Metaphysics $\Lambda$, in Giancarlo Movia, Alessandro di Afrodisia e la «Metafisica» di Aristotele (Milano, Vita e Pensiero 2003), pp. 187-218.

Sorabji, Richard, Necessity, Cause, and Blame: Perspectives on Aristotle's Theory (London, Durckwort 1980).

Tarán, Leonardo, Syrianus and pseudo-Alexander's commentary on Metaph. E-N, in Paul Moraux, Aristoteles Werk und Wirkung, Bd. 2: Kommentierung, Überlieferung, Nachleben (Berlin, De Gruyter 1987), pp. 215-232. 